
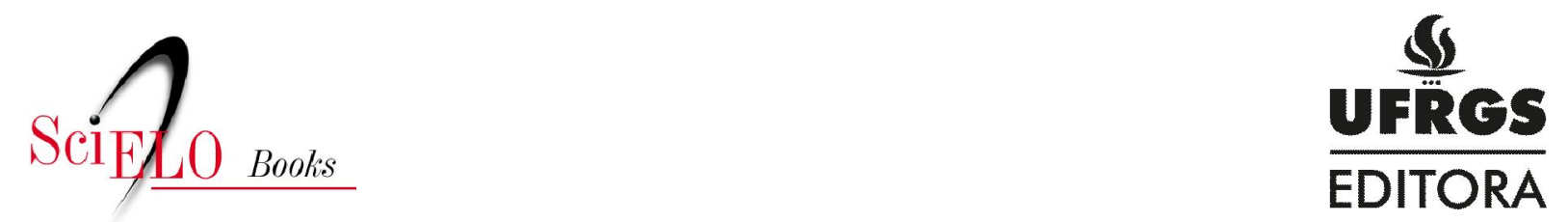

\title{
Temporalidade e corrupção da memória
}

\author{
Paulo Silveira
}

\section{SciELO Books / SciELO Livros / SciELO Libros}

SILVEIRA, P. Temporalidade e corrupção da memória. In: A página violada: da ternura à injúria na construção do livro de artista [online]. 2nd ed. Porto Alegre: Editora da UFRGS, 2008, pp. 72-119. ISBN 978-85-386-0390-0. Available from doi: 10.7476/9788538603900. Also available in ePUB from: http://books.scielo.org/id/2pwn4/epub/silveira-9788538603900.epub.

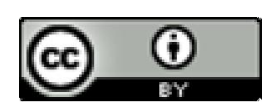

All the contents of this work, except where otherwise noted, is licensed under a Creative Commons Attribution 4.0 International license.

Todo o conteúdo deste trabalho, exceto quando houver ressalva, é publicado sob a licença Creative Commons Atribição $\underline{4.0}$.

Todo el contenido de esta obra, excepto donde se indique lo contrario, está bajo licencia de la licencia $\underline{\text { Creative Commons }}$ $\underline{\text { Reconocimento 4.0. }}$. 


\section{Temporalidade e corrupção da memória}

\section{Tempos do livro e do livro de artista}

As principais raízes do repertório do livro de artista em sentido lato parecem estar na ação crítica ou no uso concordante das formas e regras do volumen tradicional, em suas poucas variações. A perenidade (uma quase invulnerabilidade histórica) e a credibilidade (como guarda da verdade e inspiração da fé) se constituem como duas epífitas dos seus tempos. Sobretudo o que busco movimentar neste instante do trabalho é um pequeno censo que aponte algumas ocorrências de marcas e representações temporais no livro de artista, especialmente no momento de interseção ou sobreposição com a sua forma mais radical,o livro-objeto. Mais adiante, será comentada a temporalidade através das possibilidades de seu registro, além de alguns aspectos referentes à corrupção daquela que é uma das funções do livro mais sujeitas à experimentação: a de ser um arquivo de memórias reais ou ficcionais. Ou seja, ternura como gesto de confissão ou relato íntimo, e injúria como reinvenção ou ultraje à verdade. Tentarei trabalhar principalmente entre a fé (a fidedignidade induzida pelo suporte livro) e a mentira (a corrupção da expectativa de verdade que ele originalmente contém). Não será o caso, aqui, de se discutir a relatividade ou a pureza da ideia de "verdade", no singular ou no plural, assunto que tem outros sítios mais férteis. Contorno a polêmica e peço que sejam atribuídas aspas mentalmente a todas as ocorrências da palavra verdade que se seguirem.

O primeiro grande elemento ordinal no livro é a sequencialidade na percepção ou na leitura. Ela é a diretriz da ordem interna da obra, envolvendo a interação mecânica do leitor ou fruidor. Um livro envolve o tempo de sua construção e os tempos de seu desfrute. Cada vez que viramos uma página, temos um lapso e o início de uma nova onda impressiva. Essa nova impressão (e intelecção) conta com a memória das impressões passadas e com a expectativa das impressões futuras.

O segundo elemento ordinal é a serialidade. Ela diz respeito ao entendimento da obra na sua inserção cronológica e estilística em relação às obras que a precedem e às 
que a seguem, quando há, de fato, diálogo entre elas. Sequencialidade e serialidade são elementos tão definidores da estrutura física da obra que se tornam presentes pela materialização. Isso acontece, por exemplo, num número de página (fólio), que tem papel importante na obediência ou denegação da ordem. Por isso, deixarei uma parte desses problemas para a próxima seção do trabalho, sobre corpo e estrutura. Mas sua discussão já será iniciada logo adiante.

Da mesma forma, ficarão para o final da outra parte, as grandes cicatrizes que o volume sofre na emulação da passagem do tempo, para a crítica de problemas sociais ou na simbolização de estados de alma.

O livro tradicional, convencional, também tem seus tempos. Seu estado de presença comporta, além da percepção de sua fisicalidade, tanto seus ritmos de leitura como seu conteúdo de memória. Mas num livro de artista, sua inerência especial deve estar projetada no seu objetivo: ele se propõe a um desfrute além da leitura convencional (ou tradicional). O livro de artista não é, absolutamente, literário (embora possa conter literatura). O tempo pode estar além da elocução. Pode estar na sua realidade cronológica (histórica). Pode estar no momento perceptivo do fruidor. Pode ser a duração de seu próprio desfrute, ou a sua própria proposta (assunto). Em todo caso, sua evidência estará potencializada pela concepção plástica da obra, na qual a estrutura é um predicado semântico.

O escrito, a palavra impressa, é um elemento conservador, fixo e durável, enquanto as leituras são elementos da ordem do efêmero. O problema, apontado por Roger Chartier (1994, p.11), diz respeito a imponderabilidade de se historiar o efêmero da leitura, prática que quase não deixa marcas. Cita Michel de Certeau: "A escrita acumula, estoca, resiste ao tempo pelo estabelecimento de um lugar, e multiplica a sua produção pelo expansionismo da reprodução. A leitura não se protege contra o desgaste do tempo (nós nos esquecemos e nós a esquecemos); ela pouco ou nada conserva de suas aquisições, e cada lugar por onde ela passa é a repetição do paraíso perdido." Essa reflexão envolve espaço, tempo e memória. O tempo, especialmente, e suas marcas e representações no moderno livro de artista, ainda são um aspecto pouco visitado por críticos de arte. Estou considerando, neste momento, a palavra "tempo" em um sentido bastante amplo, na totalidade dos significados expostos por Japiassú e Marcondes, 1996, p.258 e 259. Envolve a noção de período entre eventos considerados como anterior e posterior, o "movimento constante e irreversível através do qual o presente se torna passado, e o futuro, presente", bem como a medida dessa mudança. Os autores citados apontam a distinção entre tempo e duração no pensamento de Henri Bergson. Tempo seria a "realidade abstrata, homogênea, divisível em instantes", sendo uma construção do mundo social e científico, e duração é "dado imediato da consciência, apreendido pela consciência subjetiva e que dá sentido à nossa experiência", que só pode ser percebido intuitivamente. Por necessidade de exposição, utilizarei os conceitos em sobreposição.

O livro é um objeto contenedor de informações que no seu processo de comunicação com o leitor se dá em momentos. Que configuração tenham esses momentos é algo que 
depende do que possamos entender como a unidade mínima que nos interessa. Se abstrairmos o conteúdo textual e o considerarmos apenas como uma textura da página, a unidade seria a página ou a mancha de texto impresso? Se consideramos o texto, com sua semântica e sintaxe, então qual seria a unidade mínima? A palavra escrita ou o seu significado? Ou quem sabe apenas o aspecto formal de um único sinal gráfico? No caso de uma ilustração, certamente poderíamos localizar percursos internos a ela, implicando em

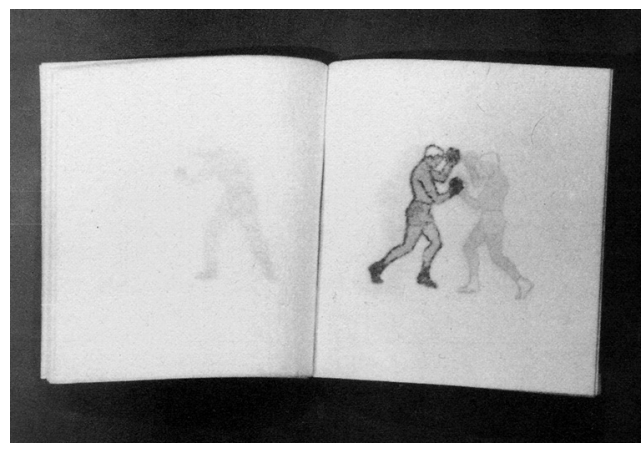

Ulises Carrión, Mirror Box, 1979 (Books by Artists, 1981, p.62). leituras iconológicas. Ir e vir de um elemento da página para outro, ler seus significados, ler a estrutura interna da página, etc., num sem fim de significados, formas e espaços. Keith Smith (1995) apontou os diversos itinerários percorridos através do livro pelos processos de apreensão: referência direta (onde se cria um movimento construído de um objeto para outro), referência randômica (associação livre do leitor), referência contígua (de uma unidade gramatical para a seguinte), referência contingente (de uma unidade ou ideia para outra não adjacente), leitura randômica, visão consecutiva e não-consecutiva, e outras possibilidades híbridas. Só isso já envolve tempo. Um tempo que podemos conceber como semelhante ao cinematográfico porque envolve movimentos internos ou externos, gestos, percepção de ordens e sequências.

Ulises Carrión, no seu artigo-manifesto já comentado e muito divulgado, apresentou o que ele denominou "a nova arte de fazer livros", ${ }^{11}$ enfatizando de momento a momento sua inter-relação temporal (Carrión, 1975).

Um livro é uma sequência de espaços. [...] Cada um desses espaços é percebido num momento diferente - um livro é também uma sequência de momentos. [...] Um texto literário (prosa) contido num livro ignora o fato de que o livro é uma sequência espaço-tempo autônoma. Uma série de textos mais ou menos pequenos (poemas de outro) distribuídos por todo o livro, seguindo uma disposição específica, revela a natureza sequencial do livro. Isto o revela, talvez o utilize; porém não o incorpora ou assimila. [...] A linguagem escrita é uma sequência de sinais expandindo-se dentro de um espaço, a sua leitura ocorre no tempo. O livro é uma sequência espaço-tempo. [...] Na velha arte, o escritor escreve os textos. Na nova arte, o escritor faz os livros. [...] Fazer um livro é realizar esta sequência espaço-tempo ideal por meio da criação de uma sequência de sinais paralela, sendo ela verbal ou outra. [...] Um livro é um volume no espaço. [...] Este é o verdadeiro fundamento da comunicação que acontece através das palavras - seu aqui e agora. A poesia concreta representa uma alternativa para a poesia. Os livros, considerados como sequências autônomas de espaço-tempo, oferecem uma alternativa a todos os gêneros literários existentes. [...] A linguagem da nova arte é radicalmente diferente da linguagem diária. Ela negligencia intenções e utilidades, e retorna a si mesma, se auto-investiga, procurando

\footnotetext{
${ }^{11}$ Embora publicado originalmente no México, esse artigo ganhou o mundo quando publicado em Second Thoughts, Void Distributors, Amsterdam, 1980.
} 
por formas, por séries de formas que dão a luz, ligam-se, desdobram-se em sequências espaço-tempo.[...] As palavras de um novo livro estão lá não para transmitir certas imagens mentais com uma certa intenção. Estas estão lá para formar, junto com outros sinais, uma sequência espaço-tempo que nós identificamos com o nome de "livro". [...] O livro mais belo e mais perfeito do mundo é um livro com apenas páginas em branco, da mesma forma que a linguagem mais completa é aquela que estende-se além de todas as palavras que um homem pode dizer. Cada livro da nova arte está buscando aquele livro de absoluta alvura, da mesma forma que cada poema procura por silêncio. [...] A intenção é a mãe da retórica. [...] Na velha arte, para ler a última página leva-se tanto tempo quanto para ler a primeira. $\mathrm{Na}$ nova arte, o ritmo de leitura muda, aviva-se, acelera-se. [...] A fim de compreender e apreciar um livro da velha arte é necessário lê-lo completamente. Na nova arte, você frequentemente não precisa ler todo o livro.A leitura pode parar no exato momento que você entendeu a estrutura total do livro.

A palavra grega $\beta i ́ \beta \lambda o s$ e seu correspondente latino liber designavam uma obra inteira que podia ser constituída de vários rolos. São Jerônimo se dirigia aos monges para que escrevessem livros se referindo
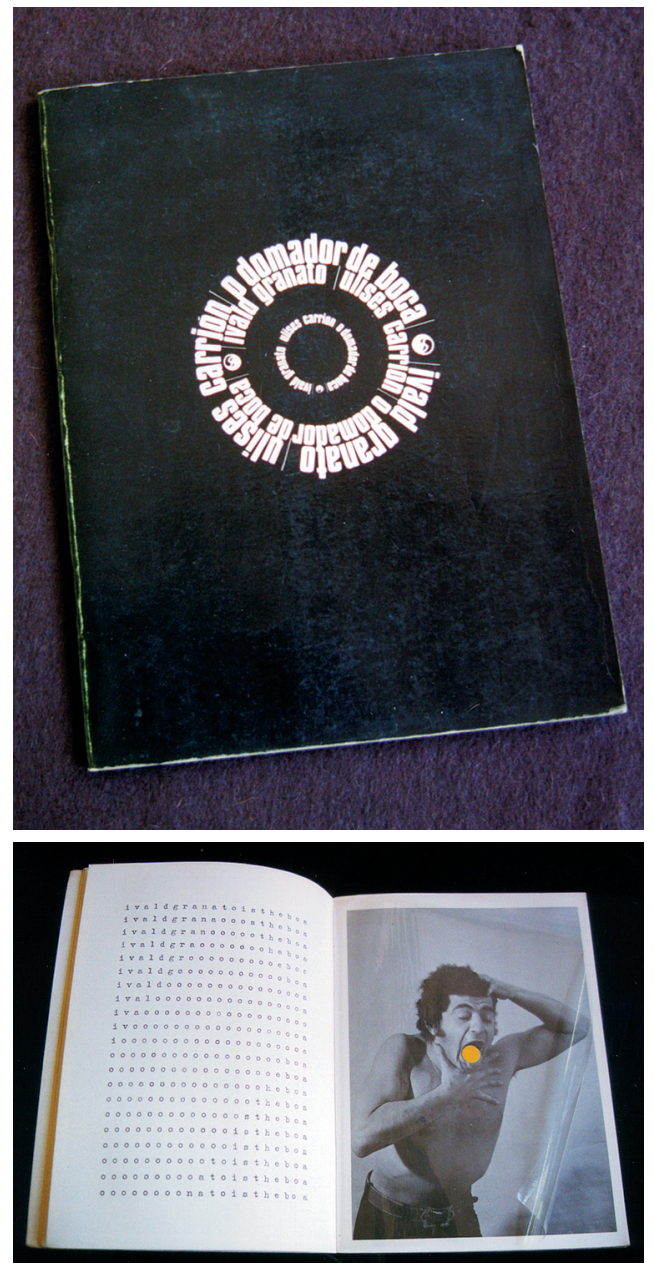

Ivald Granato e Ulises Carrión, O domador de boca, 1978. tanto à cópia do rolo como do volume, por sua vez um conjunto de livros (Arns, 1993, p.108-109). Para as Sagradas Escrituras o princípio estabelecido era de que fosse chamado volumen o conjunto de vários livros sobre o mesmo assunto. Santo Agostinho nomeia codex o objeto físico e liber as divisões da obra (unidades do discurso) (Chartier, 1994, p.102). O fato é que o próprio termo liber teve um significado muito amplo, não necessariamente atrelado à forma do códice (codex). É moderna a concepção restrita de livro, fruto da necessidade econômica de uniformização de sua forma. $\mathrm{O}$ movimento contrário a essa redução de significado acabou por ser exercido pelas próprias vanguardas da arte postal e do livro de artista, antecipados por Marcel Duchamp e outros. Pode-se dizer que essa ação intermidial reconheceu formas e recursos ancestrais. Essa ancestralidade por si só será parte constante do repertório de livros-objetos, principalmente daqueles que Anne Moeglin-Delcroix (1985) chamou de "condenados", "parasitados" e "táteis", ou até de livros que não são livros. Particularmente o movimento 
per se de folhear, desdobrar ou desenrolar, que mostra o que estava oculto, é quase um chavão. É a marca das etapas necessárias à leitura e percepção, que dita ritmos, já comentada pelos pesquisadores do século 4: revolvere librum usque ad extremum, "desenrolando ou desdobrando pouco a pouco seu escrito, lendo-o assim até o final" (Arns, 1993, p.110).

Há que se ter cuidado, também, com a correta concepção de página. Ela é universalmente aceita

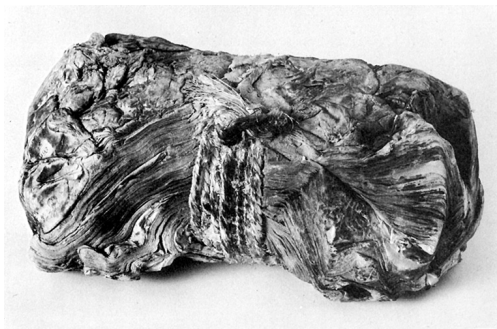

Max Sauze, Livre ficelé, 1979 (Moeglin-Delcroix, 1985, p.117). como uma unidade de construção do livro, é certo, tanto unidade de espaço, como unidade de tempo. Mas pode assumir uma representação de totalidade, como no caso da chamada page art, normalmente expressa através da presença em periódicos. Originalmente pagina era a outra designação para a superfície encerada da tabuleta que recebia a escrita, também chamada de buxa cerata. Reunidas, as páginas formavam um códice. Mas pagina também era a folha de um rolo, seja papiro ou pergaminho, considerada no todo. Nesse caso também, a consagração do códice limitou significados. A força dessa consagração pode mesmo ser verificada no mundo da computação eletrônica de dados, especialmente nas chamadas "interfaces amigáveis", programas de exibição de tela e gerenciamento de tarefas, concebidos a partir da ideia da sucessão de páginas ou de janelas interativas. Alguns programas concebidos para serem executados nesse ambiente têm inclusive a palavra inglesa book na formação de sua marca, mesmo não sendo programas editoriais (Toolbook, por exemplo). $\mathrm{Na}$ internet, rede internacional aberta de transmissão e recepção de dados, têm-se endereços (sites) chamados de páginas. Um desses endereços, The Colophon Page, é inteiramente dedicado à informação bibliográfica (incluindo o livro de artista) e à manutenção de um fórum sobre o papel da permanência da forma livro frente a essa nova realidade. Essa discussão têm sido constante, especialmente nos anos 90, pela eloquência com que se comparam o ontem e o hoje, e se especula sobre o amanhã. Chartier (1994, p.103) aponta que "esse olhar para trás, [...] essa atenção centrada sobre o nascimento do códex" acontece porque "a compreensão e o domínio da revolução eletrônica de amanhã (ou de hoje) dependem largamente de sua correta inscrição em uma história de longa duração". Na experiência civil de assistir a chegada de um novo século, de um novo milênio, convivemos com um sem-número dos mais apressados relatórios, listando todo tipo de lista dos "dez mais". Os dez melhores isso, os dez melhores aquilo. E, claro, os dez maiores inventos. E o códice ainda reina soberano. Dentre tantas matérias, encontramos no jornal um artigo de David Gelernter, crítico de arte e professor de ciências da computação em Yale. O autor é convidado a eleger o melhor desenho (projeto) do milênio, o que o coloca num impasse. Ele fica obrigado a tender entre o mostrador do relógio (século 16) e o teclado do piano (século 14). Isso porque o grande campeão, na sua opinião, o códice, embora venha atrelado ao século 15, de fato surgiu antes da Roma clássica. Em suas palavras: 
O resultado é tão compacto e conveniente, tão durável e fácil de operar, que é classificado como a obra-prima ergonômica de todos os tempos. Substituir os livros por computadores é como substituir flores frescas pelas de plástico. (Zero Hora, 27/12/1999, p.41, caderno "O melhor do milênio", originalmente produzido pelo The New York Times Magazine.)

O livro de artista é uma categoria (ou prática) artística que desenvolve tanto a experimentação das linguagens visuais como a experimentação das possibilidades expressivas dos elementos constituintes do livro ele mesmo. $\mathrm{O}$ transporte do significado do texto para o volume em si pode ser muito radical, caso específico em que a obra passa a ser denominada livro-objeto. Assim, nem todo livro de artista é um livro-objeto, mas certamente todo livro-objeto é um livro de artista. Seu repertório é infinito. Mas registra com muita frequência a inclusão de comentários e registros temporais.

\section{Tempo como ilustração e narrativa}

Pode-se identificar dois grupos principais de aportes temporais no livro de artista, através de suas páginas ou do volume como um todo. Em ambos o tempo se apresenta tanto como elemento estrutural como tema (assunto), num caso presentificado pela ilustração, noutro, pela personificação.

No primeiro grupo, inserido num grupo maior de livros sistêmicos (conceituais, geométricos, etc.), o tempo é representado ou reproduzido ou encenado. Trata-se de um tempo literário, poético, que frequentemente se utiliza da imagem bidimensional, como a fotografia, num processo de montagem com sequencialidade semelhante à cinematográfica.

Não devemos nos confundir com o livro de fotografias tradicional. No caso que estudamos, podemos associar o fenômeno com alguns pontos dos estudos de Gilles Deleuze sobre cinema. "Por um lado não há presente que não seja obcecado por um passado e por um futuro, por um passado que não se reduz a um antigo presente, por um futuro que não consiste em um presente por vir. A simples sucessão afeta os presentes que passam, mas cada presente coexiste com um passado e um futuro sem os quais ele próprio não passaria."(Deleuze, 1990, p.52) Nesse caso, o livro de artista bebe da montagem cinematográfica. Assim, uma imagem pode ser seguida de outra, cronologicamente encadeada, gerando tensão plástica e expectativa. A forma mais simples de apresentação é a que utiliza a imagem fotográfica como documento da passagem do tempo. (Mas essa me parece uma solução ainda distante do comentário temporal através da presença física do volume.) A característica do folhear, típica do livro, também é muito utilizada, com o tempo se realizando pela equação do movimento e do espaço. Buzz Spector (1995, p.9 e seguintes) diz que a leitura como um empenho toma tempo real, como uma narrativa textual ou pictórica que se desenvolve através de muitas viradas de páginas. Seu fracionamento estrutural de informação obriga a atenção a uma duração, num período de tempo passível de interrupção ou suspensão pelo leitor/fruidor, ou adiamento, ou rápida "vista de olhos”. Como exemplo da interseção entre processos históricos e físicos, Spector aponta 

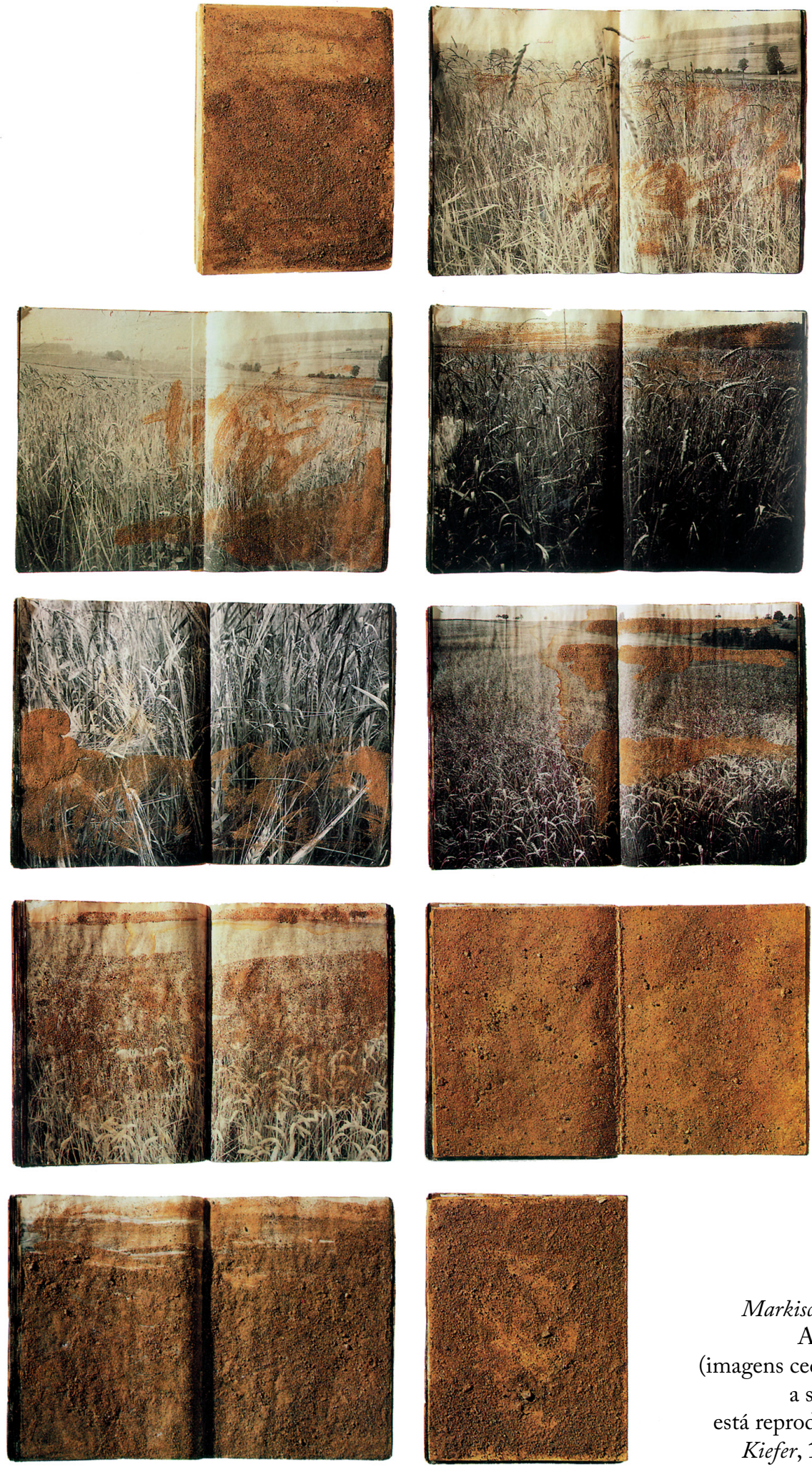

Anselm Kiefer, Markischer Sand V, 1977. Algumas aberturas (imagens cedidas pelo artista; a sequência integral está reproduzida em Anselm Kiefer, 1997, p.200-201). 
os livros-objetos de Anselm Kiefer. Ilustra seu pensamento com Märkischer Sand V, de 1977, obra com areia incrustada nas capas e partes do interior, com fotografias, e que literalmente desprende seus grãos ao se virarem as páginas. O título, Areia brandemburguesa $V$, alude a uma canção do exército alemão e a um local a sudoeste de Berlim. As fotos são de uma região agrícola. Spector prossegue seu comentário (p.17).

No início da sequência de vinte e cinco páginas duplas de Märkischer $S a n d V$, as fotografias de trigais e edificações dispersas transmitem a sensação de plenitude. Essas imagens, alternando entre detalhes de hastes de grãos e vistas de morros distantes, são no início suavemente riscadas com partículas de areia encolada. Essas manchas se tornam mais extensas conforme as páginas são viradas, até que, nas páginas finais do livro, as fotografias estão completamente enterradas sob camadas de areia e pedras. O tempo passa aqui muito eloquente e fisicamente porque com cada virada de página o leitor desperta a obra através da perda de sua substância.

Vale lembrar, como curiosidade, que na capa de seu livro citado (de ensaios), Spector reproduziu seu livro-objeto History of Europe, de 1983, composto por um livro encontrado, com cimento derramado sobre ele. Essa obra pode ser enquadrada no segundo grupo, tratado mais adiante.

O tempo de Kiefer transcorre silenciosamente no espaço entre a narrativa e a dissertação. Não parece haver tempo sem espaço na sua obra, onde os títulos esclarecem o quando, o onde ou o quê. Sua memória não é mística, como esclarece Alberto Tassinari:

A arte de Kiefer, como a dos deuses embalsamadores, é uma arte da regeneração, e, na medida em que a questão de todos os seus temas é o passado, uma arte de regeneração da memória do mundo. [...] Se é toda a memória do Ocidente que a obra de Kiefer, a seu modo, aborda, o que é notável é como, para onde for que se dirija no passado ocidental, aí acabará por encontrar temas de destruição e reparação a serem, eles mesmos, esteticamente expostos como destruídos e reparados. (Anselm Kiefer, 1998, p.13)

Kiefer escolhe com clareza os momentos do passado a serem trabalhados, sem dispersão de um eixo ético. Ao que prossegue Tassinari:

Se a memória é seu assunto por excelência, cada obra quase sempre retoma em parte as anteriores. À maneira de um historiador, Kiefer trabalha a memória de todos. Como artista, lembra os passos que constituíram sua trajetória. Parece ser com tal interpenetração, camada sobre camada, que sua obra testou-se e ganhou força. [...] Pouco a pouco, através sobretudo de aquarelas e livros artísticos, sua obra foi traçando vínculos entre procedimentos da arte contemporânea e o significado de tradições em geral, não apenas alemãs. [...] $O$ passado, o mítico, o religioso e o arcaico não são inacessíveis. (p.17)

No território dos livros mais vigorosamente plásticos, as recorrências formulistas, os recursos dramáticos exacerbados e os embalsamamentos são, às vezes, tão intensos que nada mais fazem do que congelar a obra para os nossos sentidos. Existe um caudaloso rio de soluções realmente exasperantes que empurram para baixo o número de sucessos nos livros-objetos mais escultóricos. Uma das metáforas mais frequentes é a do livro imobilizado sem páginas (ou tempos) para virar. Abdica-se do ritmo, da memória do que foi visto, da expectativa do que está para se ver, da relação no presente entre momentos passado e futuro. 


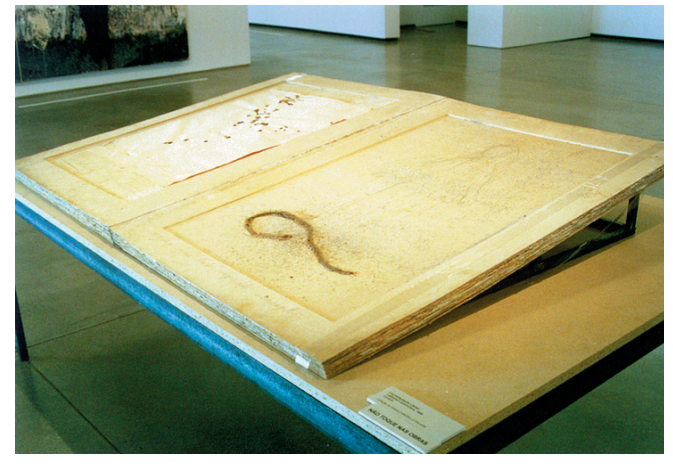

Laurentanische Litanei

(Ladainha Laurenciana), 1996.

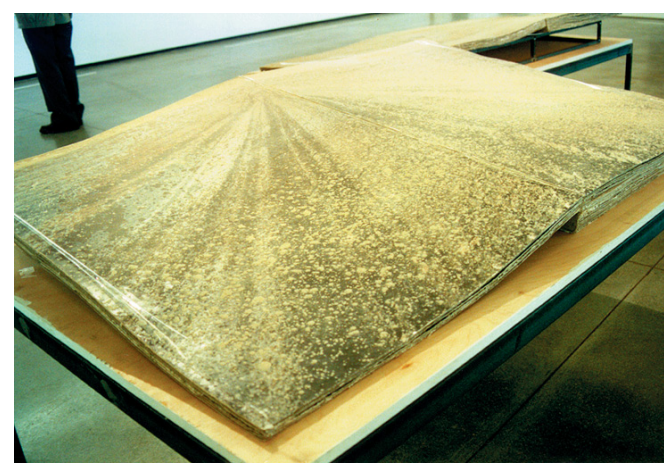

Better red than Dead

(Antes vermelho do que morto), 1997.

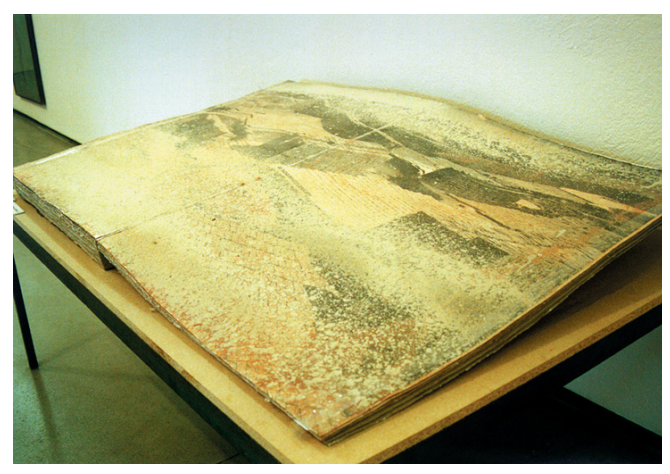

Ur, 1997.

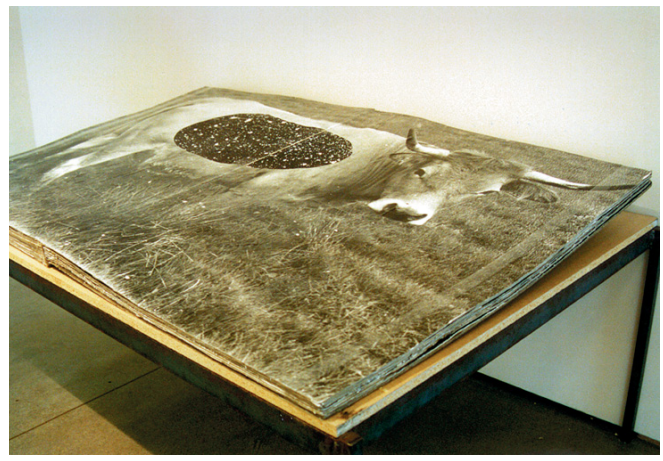

L'Auvergne, 1996.

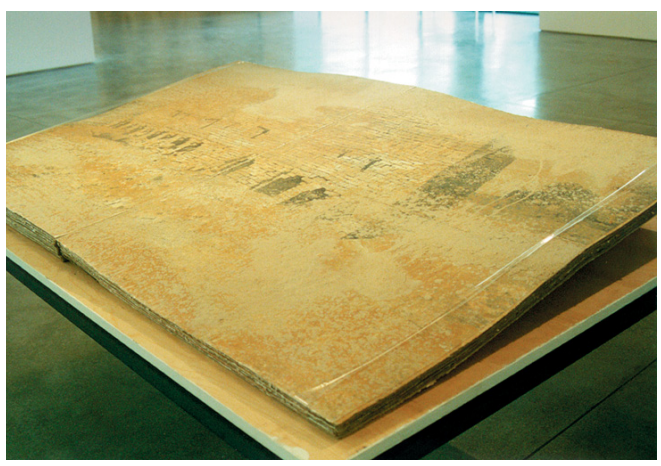

Dein und mein Alter Und das Alter der Welt

(Sua idade e a minha e a idade do mundo), 1997.

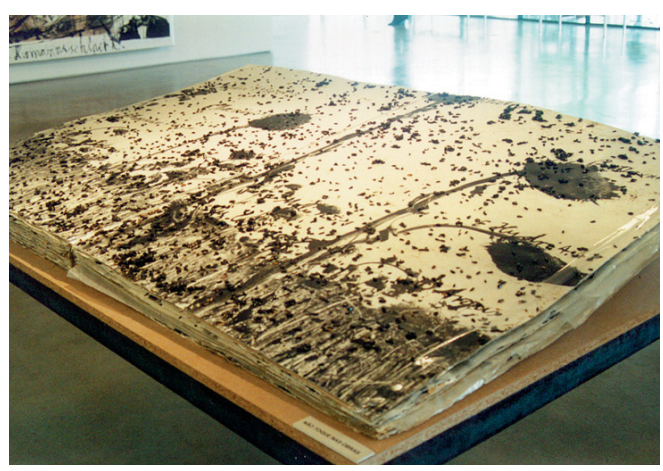

The Secret Life of Plants

(A vida secreta das plantas), 1998.

Livros de Anselm Kiefer em exposição no Museu de Arte Moderna de São Paulo, em 1998. 

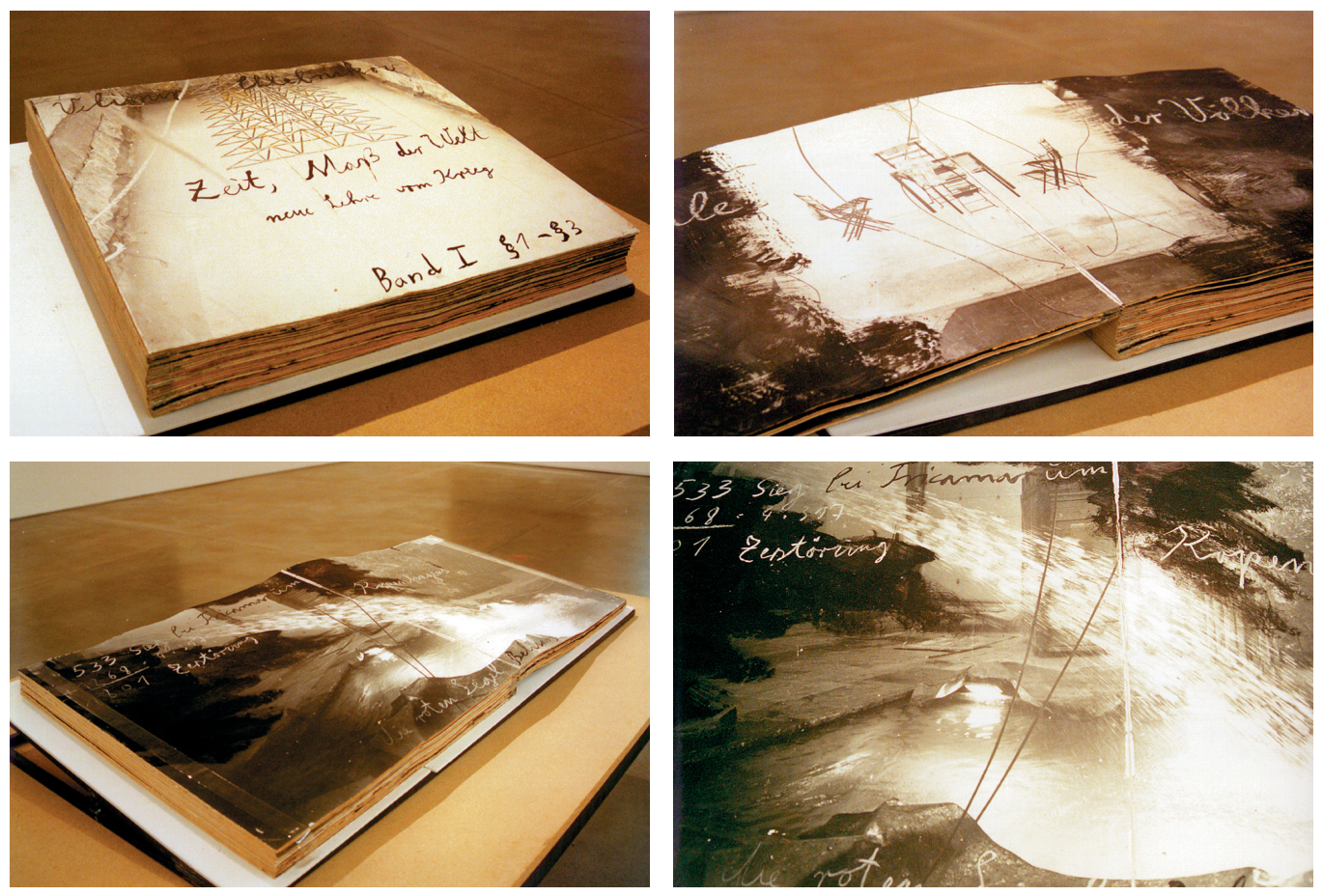

À esquerda, Velimir Chlebinokor, Zeit, Mass der Welt, Band I

(Vladimir Khlebinokov, Tempo, Medida do Mundo, Volume I), 1997.

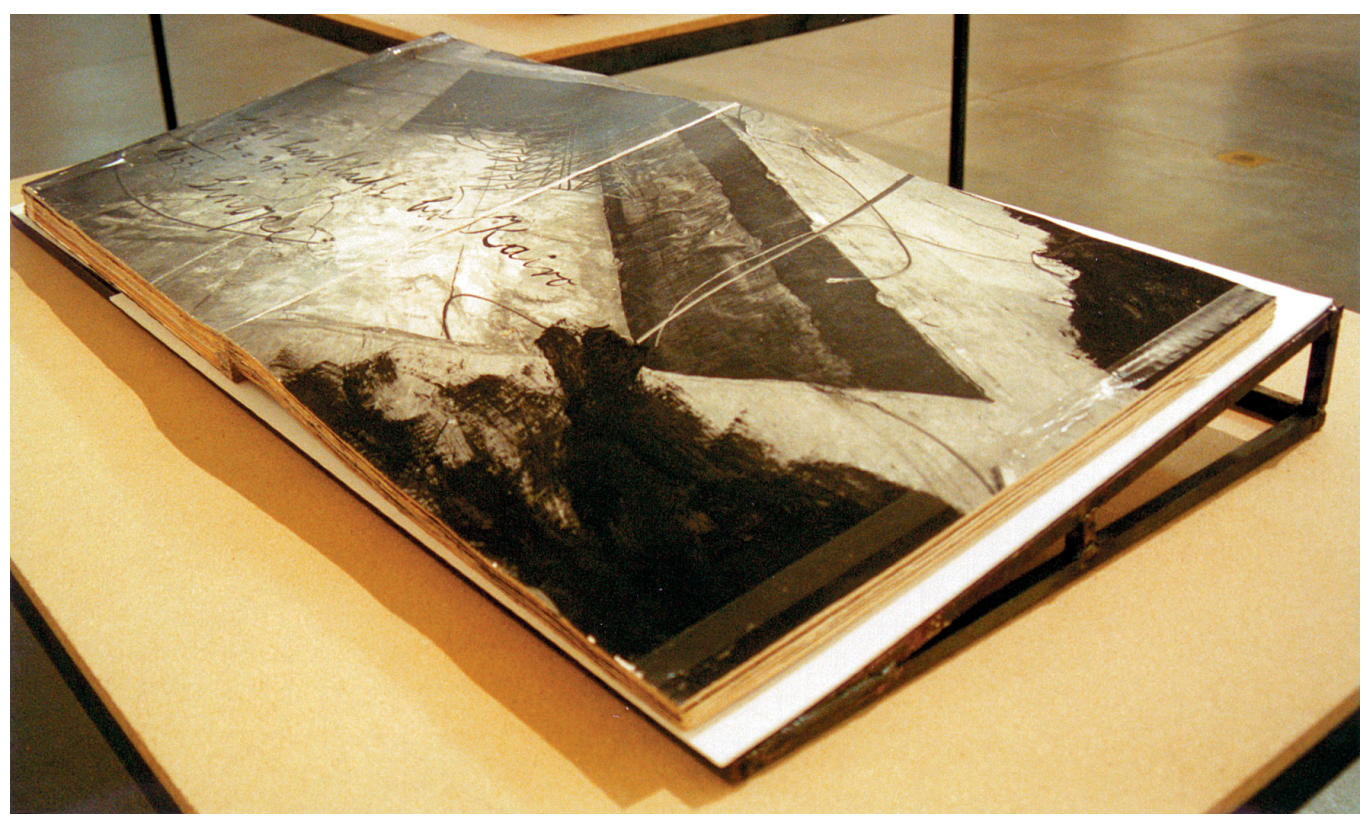

Velimir Chlebinokov, Zeit, Mass der Welt, Band II

(Vladimir Khlebinokov, Tempo, Medida do Mundo, Volume I), 1997. 
Resta o comentário aforístico.É uma realidade que faz com que estudiosos e críticos tenham confessadas reservas ao geral dessa produção. Destinam seus elogios para poucos nomes. E, dentre eles, a unanimidade a respeito de Kiefer, que poderia definitivamente fixar suas páginas com chumbo, mas não o faz. Por mais monumentos que sejam, eles permitem (e exigem) o folhear. São o que parecem ser: livros.

Talvez um exemplo mais evidente (porque simples) do recurso à narração associado ao ato de virar as páginas seja o dos livros integralmente fotográficos, onde uma sequência intencional, vinculada à noção de etapa, gera drama. É o caso de Cover to cover (Nova Scotia College of Art and Design e New York University Press, 1975), em que Michael Snow subverte o códice pelo comentário de sua estrutura, que aqui é elaborada com um rigor extremado. Fotos de página cheia de portas que abrem e fecham ocupando toda a página, permitem que o trabalho seja desfrutado numa direção ou na outra. Uma mesma cena é mostrada em frente e verso, em páginas lado a lado.

$\mathrm{O}$ que percorremos? A residência do artista e seus arredores ou as páginas de um livro? As mãos de Snow aparecem em tamanho natural, folheando as páginas de seu próprio trabalho. Vemos o que o artista vê, tal como numa câmera subjetiva. Simultaneamente (ou às vezes sucessivamente) o artista (o "ator") é visto pelo leitor/fruidor. Os tempos se articulam no plano conceitual intelectivo e no plano físico da obra. O leitor "narra" a obra, que por sua vez também se narra. Os "atores" se confundem.

O uso da sequência por narrativa visual, literária ou estrutural é de importância básica para a caracterização da identidade do livro de artista, principalmente se ele for uma peça múltipla. Dieter Roth (1930-1998) e Sol LeWitt, por exemplo, têm, cada um, uma muito particular maneira de lidar, nos seus livros, com sequências narrativas não literárias, em acordo com a diversidade de suas obras (por exemplo, entre outros, a pesquisa geométrica). Johanna Drucker, em seu livro The century of artists' books (1995, p.257), acentua a importância definidora dos elementos estruturais:

Finitude e sequência são dois elementos estruturais fundamentais de um livro. Os limites de um livro - seus parâmetros em espaço e tempo e seus limites físicos demarcados - são tão fundamentais que somente dentro de proposições conceituais desmaterializadas ou espaço eletrônico podem eles ser suspensos. $\mathrm{O}$ uso da sequência varia de livro para livro. Mesmo a necessidade da sequência fixa não se aplica universalmente - pode ser argumentado que certos "livros" que são elaborados por conjuntos de cartões ou elementos soltos ainda permanecem sob a definição de uma forma livro. 

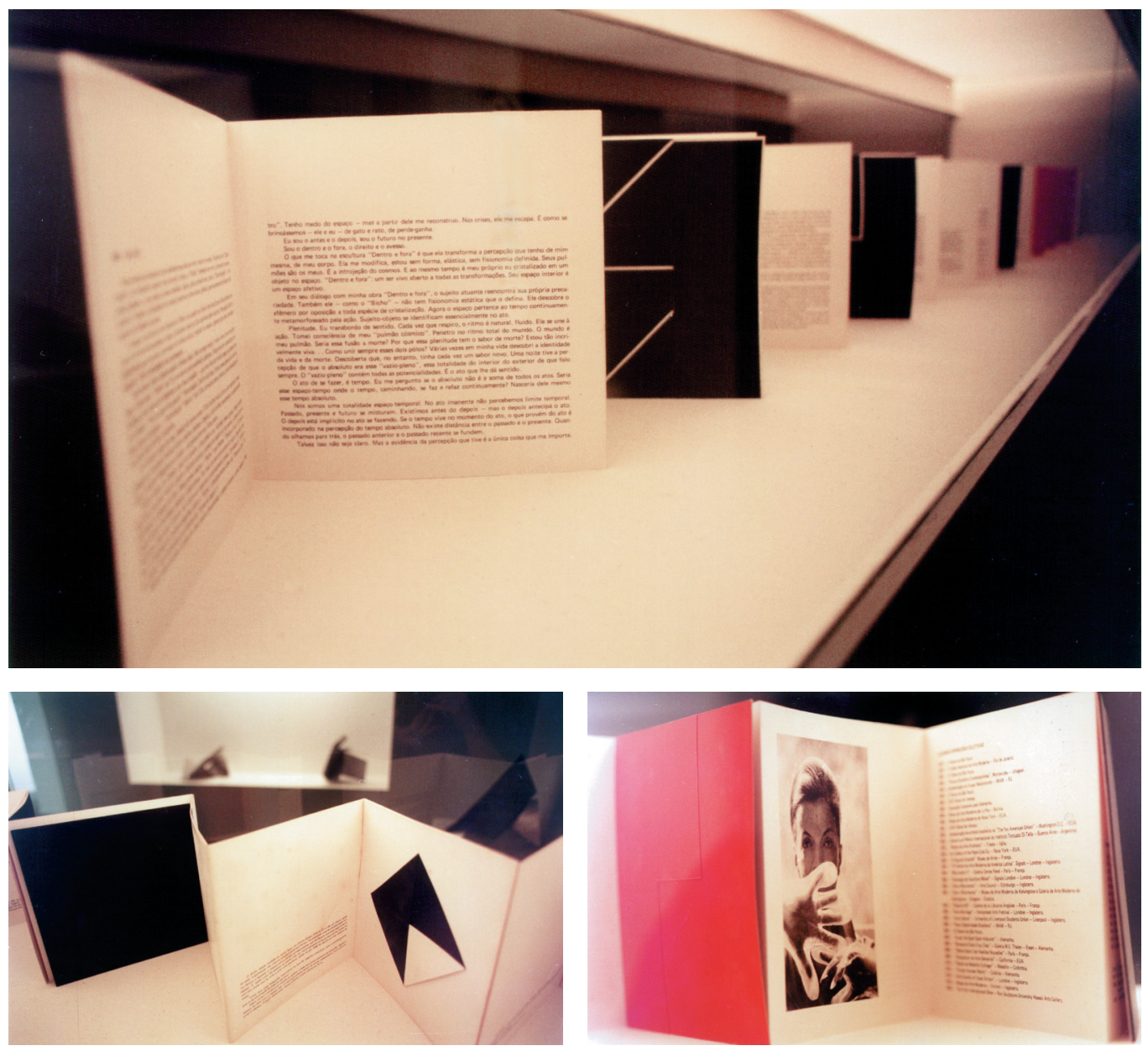

Lygia Clark, Livro-obra, 1983, na I Bienal de Artes Visuais do Mercosul, 1997, em Porto Alegre. Coleção Luiz Buarque de Hollanda. Fotos de Júlio Cordeiro, Banco de Dados do jornal Zero Hora.

A narração também pode envolver a sequencialidade por si só, sem elocuções lexicais, apenas com expressão $0^{12}$ plástica. Ela também pode ser encontrada nos trabalhos que usam dobraduras e apêndices (encartes), podendo-se expressar tanto pelas possibilidades de articulação, como pela surpresa das presenças e das ausências. Em alguns casos é necessário algum conhecimento de encadernação ou artesanato (especialmente por suas possibilidades cinéticas e a necessidade de articulação ou agregação de materiais diversos), como em Robert Filliou, Susan King ou Kevin Osborn. Frequentemente, o tempo aqui

\footnotetext{
${ }^{12}$ Aqui, como em outros momentos deste trabalho, utilizo a palavra expressão conforme o uso geral, como sendo a enunciação de uma ideia ou sentimento, tornada compreensível através de qualquer meio. Esse entendimento não está em desacordo com a definição proposta por Arnheim (1989,p.438), onde a expressão é definida "como maneiras de comportamentos orgânico ou inorgânico revelados na aparência dinâmica de objetos ou acontecimentos perceptivos".
} 
é o tempo presente do manuseio, muitas vezes mais eloquente que o tempo passado ilustrado visualmente. Isso fica mais evidente nas elaborações em sanfona (ou acordeão, ou concertina). Esses trabalhos formam um universo muito amplo, com experimentações de muitos artistas, como Edward Ruscha, Keith Smith, John Baldessari, e outros. Lygia Clark, no seu Livro obra (1964/1983, tiragem de A a Z), faz da dobradura em sanfona suporte para texto escrito (que oscila entre o opinativo e o didático, os dois conceitos não se excluindo) em parceria com ilustrações e colagens acompanhados de peças móveis. É necessário tocar, manipular, jogar com Lygia. Não há como não "ler" o projeto que proporcionou a obra. Não há como não antever o resultado de nossa manipulação. A retina oscila entre o todo e o detalhe, entre a articulação e o recorte. Essa oscilação (movimento) nos força a um plano específico de atenção nas condições ambientais. A coisa é o imóvel; o evento é o móvel.

Um exemplo de trabalho com dobraduras e articulações que envolve as relações entre seus diversos tempos é o livro-objeto em peça única de Susan Share, Midnight puzzle, de 1989, em papel, tecido, cartões,

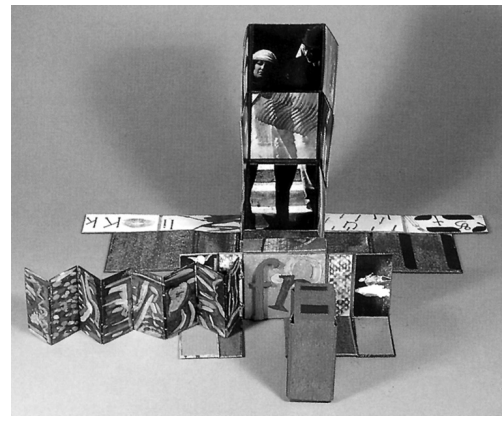

Susan Share, Midnight puzzle, 1989 (Book Arts in the USA, 1990, p.48).

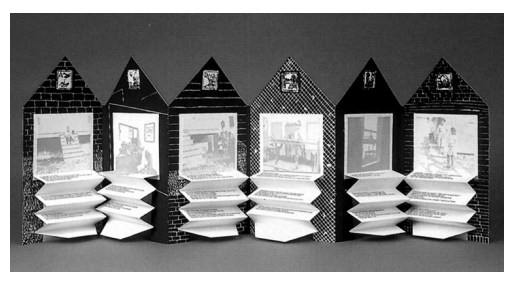

Clarissa Sligh, What's happenig with momma?, 1988 (Book Arts in the USA, 1990, p.49). tinta acrílica e fotos, com 53 páginas interconectadas. Além das possibilidades de manuseio, é importante ressaltar que muitas de suas obras fazem parte integrante de performances $\mathrm{da}$ artista. Seus tempos, assim, se multiplicam em pontuação cênica e coreografia.

Minha exploração dos livros como uma forma artística inclui trabalhos de pequena e larga escala. Eles investigam movimento, som e transformação, assim como estrutura, cor e padrão. Eu incorporei o conhecimento obtido através do meu trabalho no campo da encadernação tradicional e conservação dentro do meu trabalho como uma artista visual; e minha obra visual, dentro da performance, criando, assim, "livros-performances". Através da manipulação brincalhona por performers, eu apresento o "livro" como um objeto em movimento, tornando acessível ao observador a informação contida nele. (Book arts in the USA, 1990, p.48)

No mesmo catálogo que reproduz a citação acima (que acompanhou a exposição itinerante A Arte do Livro nos Estados Unidos (Book Arts in the USA), que, no Brasil, esteve no Rio de Janeiro e em São Paulo), está o livro em sanfona ou acordeão de Clarissa Sligh, What's happening with momma?, 1988, com tiragem de 150 exemplares em serigrafia, produzido pelo Women's Studio Workshop. Clarissa fala, em seu depoimento, de uma outra temporalidade (p.49):

Meu trabalho é uma tentativa de representar a conexão sempre presente do que já aconteceu com um tipo de presente continuado. Começo com a fotografia, uma criação de tempo 
e luz. Contra ela eu justaponho outras fotografias, marcas ou palavras. Usando velhas fotos de família, eu reconstruo meu eu. Eu refotografo e reimprimo, escrevo e reescrevo. Tento conectar com o que eu era. Desse ponto, uma direção flui pelo que faço.

Como combino elementos de marcas e fotografias dentro de um enquadramento, elementos de tempo sucessivo e simultâneo são trazidos ao presente em um lugar, um movimento, um evento. Ao construir o incontável, o indizível, e o irrepresentável através desse processo de reenquadramento, uma cura acontece.

O tempo da experiência me ensinou que cada marca que faço, cada palavra que escrevo é atada a cada gesto que eu já tenha feito. A história tem me ensinado que cada fotografia que faço é ligada com cada desenho, impressão e pintura que o gênero humano tem feito.

Segundo Rudolf Arnheim (1989, p. 367), a percepção da estrutura de obras como um filme ou uma sinfonia, como na pintura, precisa ser totalizadora no que diz respeito à apreensão de sua sequencialidade. A totalidade da obra precisa estar "simultaneamente presente na mente se quisermos entender seu desenvolvimento". A percepção da estrutura "requer simultaneidade e por isso dificilmente é temporal" (no sentido de que "uma fase desaparece à medida que a próxima ocupa nossa consciência"). E prossegue: "Juntos, os meios sequenciais e não sequenciais interpretam a existência em seu aspecto duplo de permanência e transformação" (p.370). Lygia sabia o que era um livro de artista e conhecia a estrutura espacial da memória. Estava integrada na conceitualização da intermídia (conceito desenvolvido por Dick Higgins, comentado mais adiante).E, como poucos, jogou com esses conceitos. No Livro-obra, trabalho fortemente intelectualizado, há temporalidades parciais dentro da temporalidade totalizadora.
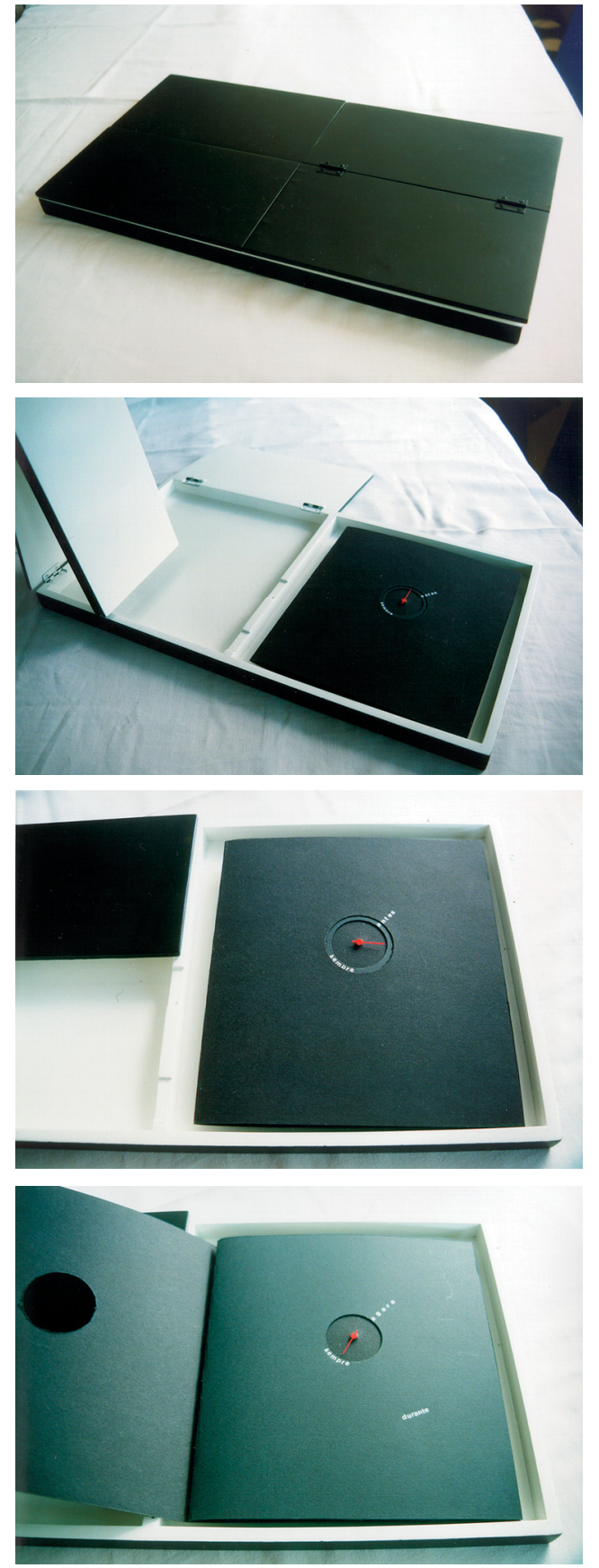

Lula Vanderlei, Geometria do tempo, 1994. 
Alfred Gell (1992, p.120) lembrou que as inflexões verbais indicam em que momento ou em que intervalo de tempo as ações acontecem. Para ele, o mais adequado modelo de análise das inflexões é o sistema introduzido por Hans Reichenbach em obra de 1947, Elements of symbolic logic. Ele teria sido o primeiro a distinguir entre o tempo da fala, o tempo do evento e o tempo de referência. Por tempo da fala entende-se o momento em que a elocução é feita. Tempo do evento, o momento em que o evento referido acontece. E tempo de referência é o do ponto de vista temporal, que é formado sobre o evento, antes, depois ou simultaneamente a ele. Como exemplo, ele usa uma frase: "Antes que entrasse em batalha, Sir Percival confessou seus pecados". O tempo do evento é a confissão; o tempo de referência é a entrada em batalha; e o tempo da fala é o último momento em que esses eventos são narrados. Gell nota que em muitos casos esses tempos se sobrepõem, um coincidindo com outro ou mesmo todos os três se tornando indistintos. Em "os corvos são negros" todos os tempos coincidem. Em "John atravessou o Canal" o tempo de referência e o tempo da fala coincidem entre si (é presente o fato de que John já tenha atravessado o Canal uma vez), distintos do tempo do evento.

Mas existem linguagens sem inflexões. Por isso, mais universal para a linguagem é a distinção pelo aspecto. Isso refere-se à forma do evento ou do processo. Dizer que "o médico tratou o paciente" significa que ao menos o tratamento foi completado, independentemente do resultado. Nos livros de artista que estamos considerando, pode ser percebido como existe tensão entre esses tempos, bem como o artista usa essa tensão ciente do seu papel na linguagem. E, sobretudo, entrecruza as diversas falas com a presença estrutural do livro. Aliás, não devemos esquecer que o livro é sempre presente. Sabe-se que ele sobreviveu ao passado e, espera-se, prosseguirá no futuro. Carrega consigo o mito de ser uma cápsula do tempo que comporta as "verdades da lei".

\section{Tempo corporificado e injúria física}

O segundo grande grupo de ocorrências temporais no livro de artista é aquele em que o artista busca a personificação do tempo. Com frequência, ele aqui é muito menos físico pelo movimento do que pela imobilidade, chegando até a ser uma vítima do tempo: ser climático. Sequencialidade e narração têm valor quase nulo. A obra, isso sim, procura a marca física do dano. Prefere, como imagem (impressão provocada), a injúria física. Através do clima o tempo pode ferir. $\mathrm{O}$ objeto artístico exibe cicatrizes que são reais ou produzidas. O comentário se faz pela própria existência percebida, que registra o momento presente, formatado pelo percurso de um passado, e que, se imagina, permanecerá para o futuro. A simultaneidade perceptiva passa a ter mais valor.

Existe um grande conjunto de obras que procura o comentário do caráter sagrado do livro, bem como a crítica ao fato de ele ser portador da força da lei. Esse segmento pode ser subdividido, grosso modo, em dois conjuntos. 
O primeiro apela para o realce da permanência do livro na história e no mundo da vida, através da maceração da página, de sua imobilização, de sua conspurcação, da maquiagem. O livro é eterno porque é imóvel. Assiste impassível aos eventos finitos. Ele é um morto-vivo ou um sentinela. Veio do passado, de onde guarda seus segredos, e permanecerá para o futuro, de onde guarda suas profecias.

O segundo conjunto é o dos livros encontrados, que são utilizados como matéria-prima para intervenções críticas, por pigmentação, recorte, perfuração, etc. Esse grupo pode, num certo modo, estar ligado ao anterior.

Nos dois casos citados predominam os exemplares em peça única, muitas vezes com algum vínculo com a escultura. Lenir de Miranda, por exemplo, circulou nos dois grupos. Mas todos os seus livros-objetos são articuláveis, propondo a quem os manuseia o exercício ritualístico de encontrar objetos e superfícies ocultos nas dobras, parafusos e presilhas que utiliza. O tempo dessas páginas “é espaço, já que seus momentos coexistem diante do pensamento, é presente, já que a consciência é contemporânea em todos os tempos" (Merleau-Ponty, 1996, p.556). Sua obra de referência recorrente é Ulysses, de James Joyce, citado ora literalmente, com escritos, ora com imagens e texturas vigorosas. Lenir se utiliza, também, de olhos-mágicos (dispositivos ópticos de segurança para portas). De alguma maneira o que eles veem está preso neles: são pequeníssimos objetos ou fragmentos aos quais não temos acesso, por estarem fechados em compartimentos do próprio livro. Deve-se olhar por eles como se olharia numa antiga máquina de cinema a manivela. Neles - utilizando ou raptando palavras de Deleuze (p.99) -, o passado coexiste com o presente que foi. "O presente é a imagem atual, e seu
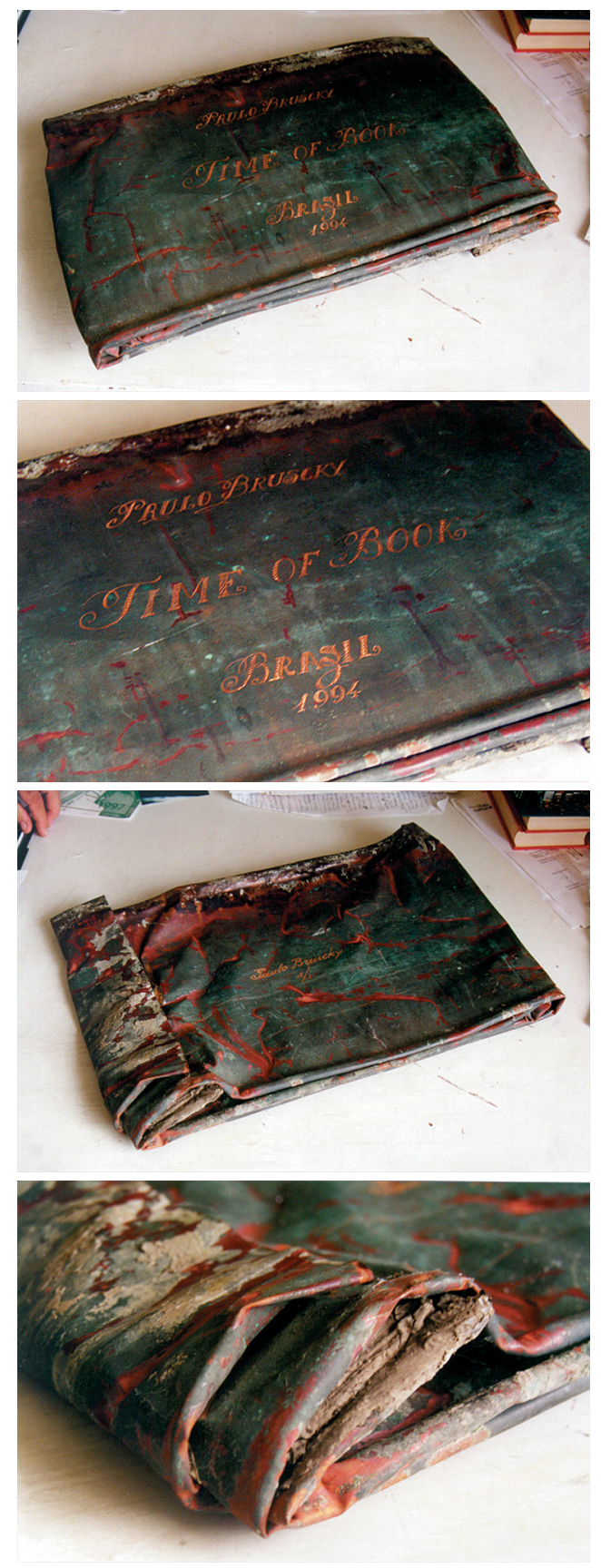

Paulo Bruscky, Time of book, 1994. 
passado contemporâneo é a imagem virtual, a imagem especular." Lenir realiza a vibração de um diapasão imaginário: seus livros são mudos, mas podemos ouvi-los.

Outro grande conjunto de livrosobjetos, embora pareca ser menor que o anteriormente descrito, é o dos trabalhos que tentam ser eles próprios o registro do tempo em movimento, pelas marcas do seu envelhecimento real (como também acontece no trabalho de Anselm Kiefer já comentado), ou por guardar dispositivos de medida (como no caso de obras de informática nas quais o leitor/fruidor intervém, com o seu momento registrado). Riva Castleman (1994, p.72), ao comentar a presença dos artistas em propostas de encadernação, destaca a capa de Barbara Kruger para a novela de horror de Stephen King, My pretty pony, 1988, "uma história sobre a natureza e significado do tempo". Internamente a obra contém as características composições de Kruger com texto e imagem (litografias e serigrafias), em contraste com o estilo antiquado de King. Mas o realmente inusual, somado ao peso de volume, é a capa feita de aço escovado. Incrustado nela, a artista colocou um relógio digital. A capa não tem título ou autor. Apenas o relógio. Que, é claro, funciona. Em catálogo de Elizabeth Phillips e Tony Zwicker (1993, p.40) o livro de Kruger é assim apresentado:

O sexto livro na inovadora série Artists and Writers, do Whitney Museum, discorre sobre a passagem do tempo ("agradável, mas com um coração mau”) e como conquistá-lo, como contado por um velho
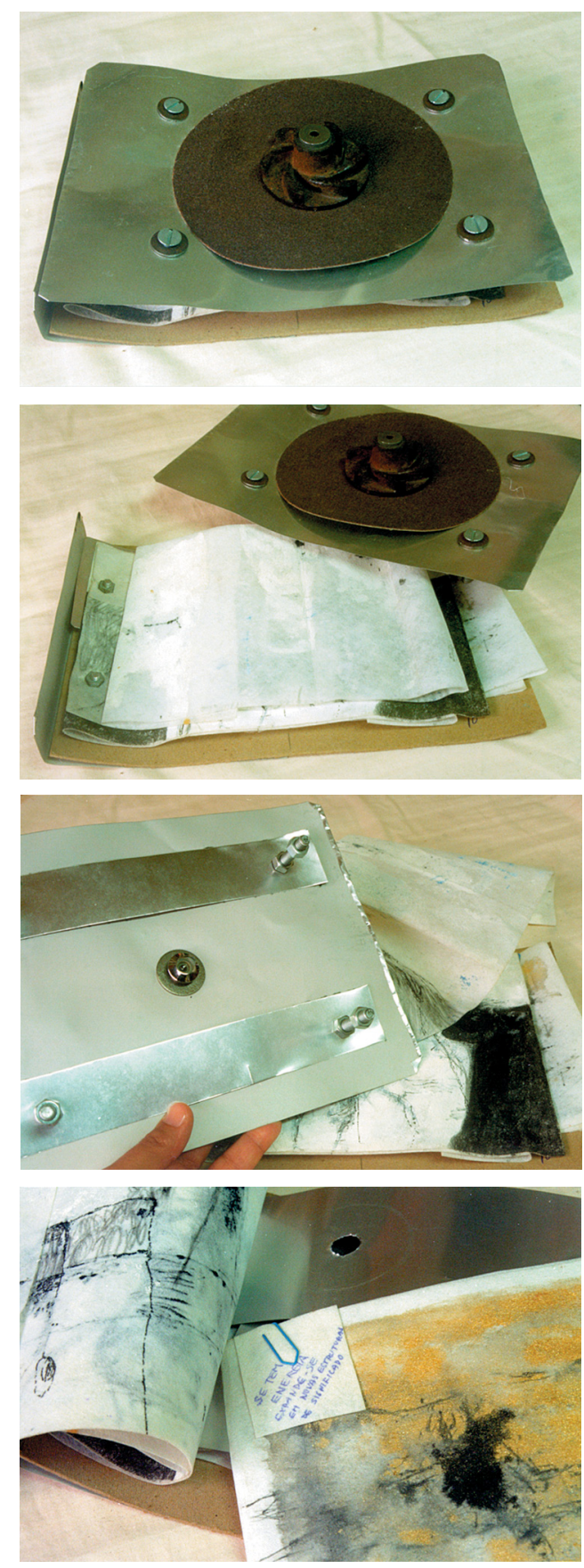

Lenir de Miranda, Livro com olho mágico, 1993. moribundo que dá seu relógio de bolso de prata para seu neto. O título da história aparece heraldicamente no começo, meio e fim do livro em tipo helvética negrito serifado em branco sobre vermelho. O texto é entremeado com litografias de Kruger baseadas em três 
fotografias de homens e cavalos. Impressas em vermelho, azul e preto, as imagens são cortadas e estouradas até os pontos da retícula de impressão alcançarem a abstração. Cada litografia também contém um pequeno quadrado mostrando uma mão de mulher premendo um cronômetro e um breve mote de Kruger.

O Center for Book Arts, de Nova York, entidade sem fins lucrativos, desenvolve cursos de encadernação tradicional e artística, além de atividades correlacionadas. Por atender, também, uma parcela da comunidade de artistas plásticos que usam o livro como veículo de expressão, realiza eventos que possam experienciar as novas propostas. Entre elas, houve uma mostra em 1987, The Effects of Time, composta por livros tradicionais anteriores a 1600, que pretendia mostrar a estética produzida por insetos, roedores e... encadernadores, usuários, etc.! Naturalmente, era uma exposição crítica. Leonard Hansen e Richard Minsky, os curadores, iniciavam assim a sua apresentação: "Um dos grandes fascínios dos livros velhos é a sua história como artefatos. Quando olhamos para livros que têm centenas de anos nós vemos notas marginais de muitos leitores, buracos queimados por cinzas de charutos, emendas manuscritas para textos sumidos, e muitas outras indicações sobre onde o livro esteve e a que riscos ele sobreviveu". Outra mostra, mais recente (1995), This Day in History... (com curadoria de Brian Hannon e 47 participantes), apresentava livros-objetos contemporâneos que lidavam com as transformações íntimas (pes-
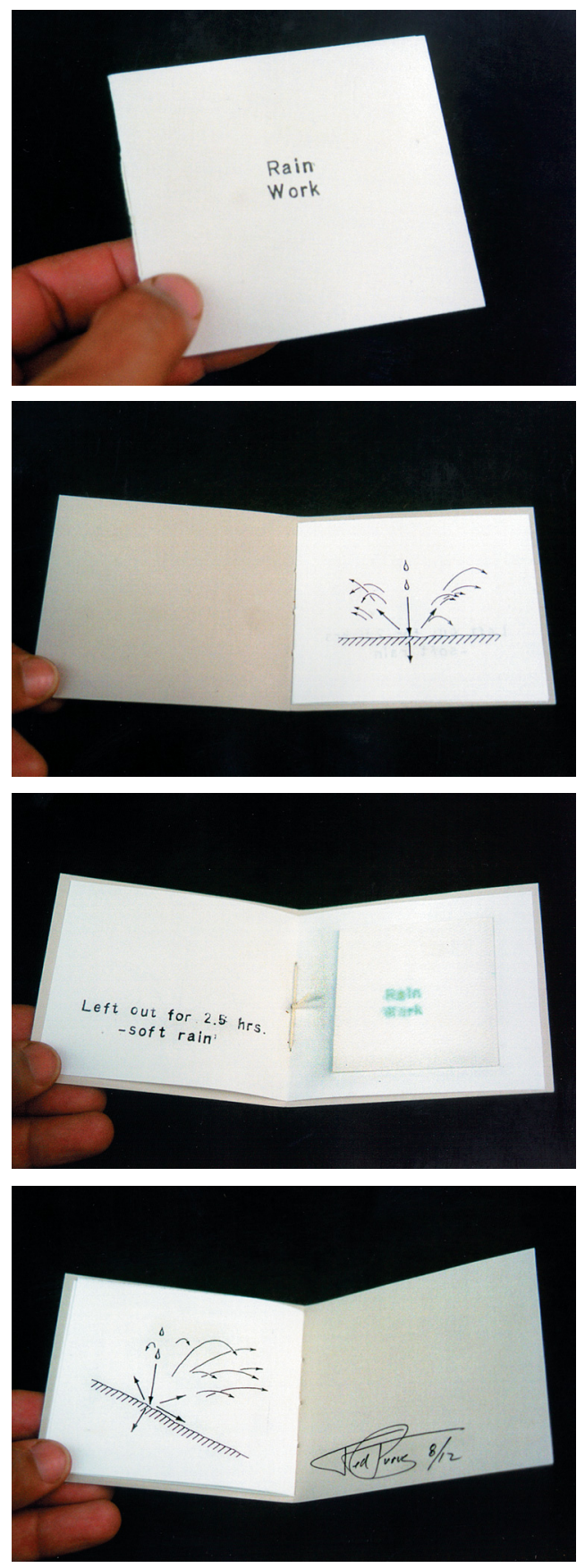

Ted Purves, Rain work, 1994. soais) associadas com o livro em si, com a história e com a verdade objetiva, marcando a confiança no conhecimento intuitivo do dia-a-dia. O que ambas as exposições demonstraram, cada uma com uma ponta da corda, foi o desejo do homem que lida com livros de ver o tempo. 
E se procurássemos as marcas do tempo pela sua tradução em acidentes climáticos? Dentre trabalhos mais grandiosos ou eloquentes, cito um diminuto livro de Ted Purves, de 1994, 8 × $9 \mathrm{~cm}$, com tiragem de 120 cópias, que pode ser comprado por apenas oito dólares. Possui capa e mais quatro páginas de papel barato, costuradas com linha branca. Rain work foi executado com o auxílio de carimbo de borracha e fotocópia. O título, com a mesma conformação tipológica da capa, foi carimbado sobre papel mais áspero e realmente colocado na chuva por um tempo determinado, o que borrou as letras. Depois, foi recortado e colado na terceira página. As páginas um e quatro possuem diagramas sobre as direções dos pingos de chuva. E na página dois, a informação: "Deixado na rua por duas horas e meia - chuva suave".

\section{Registro temporal e presentificação pelo documento}

Às considerações precedentes, deve ser acrescentado que o equilíbrio entre ternura e injúria se reflete também na presença de documentos (ou no uso que se dá a eles), quer na sua forma de registros (vestígios), quer na sua forma de testemunhos. O documento parece ser uma significativa unidade de representação de um evento, assumindo um papel de materializador do tempo histórico pessoal e social no livro de artista. Se o vestígio se propõe como uma "evidência", o documento coloca-se como confirmação do fidedigno. Comportando-se como material artístico, um e outro podem questionar seus papéis. A oposição entre verdade e mentira assume, aqui, a gerência da forma, ao exigir que o seu suporte seja preservado em sua tradição como garantia de deferimento. Tem sido pouco expressiva, no censo realizado para esse trabalho, a presença de livros-objetos limítrofes, borderlines. Ao contrário, o formato convencional do livro em brochura ou do caderno em espiral mostra ser o usual contenedor das "provas verídicas" de uma experiência pessoal. O elemento "injurioso" (entre aspas) será localizado pela omissão da verdade ou elocução da mentira. A verossimilhança pode substituir a verdade.

Como já observado, o desenvolvimento do moderno livro de artista não é um fenômeno isolado, que desconsidere seus vínculos sociais. Ao contrário, está consciente da existência de uma rede de eventos editoriais que, desde o fim da Segunda Guerra, tem-se colocado em paralelo à indústria cultural. A narrativa audiovisual, por sua abrangência, despertou um interesse que é comum a diversos campos da informação e da expressão. Esse fenômeno também é verificado pelas novas posturas dos pesquisadores em história, no que diz respeito à coleta iconográfica. No interesse de esquadrinhar relações antes pouco estudadas, minoria após minoria estão ganhando seus livros exclusivos. Pequenas histórias narradas a partir do cotidiano se impõem à tradicional história universal. São a história das tribos, dos grupos, do sujeito, em um enfoque adaptado a nossa época de visualidade extrema: a história das mentalidades, apoiada na iconografia. Michel Vovelle, pelo ângulo do historiador, atribui ao que ele denomina "imagem-testemunho" uma nova 
possibilidade de documentação: "a imagem que testemunha, que relata e que contribui, por si só, para construir o acontecimento em toda a sua espessura política, social e cultural" (Vovelle, 1997, p.22). E esse fenômeno, que percebemos estar vivendo um momento de facilitada multiplicação (já que gera bens de cons umo), teria uma forma particular de inter-relação com livro de artista? Em um movimento inverso, tem o registro participado, de uma forma renovada, da criação artística, ou ela mesma, a arte, se colocado como documento do agora? As respostas a essas perguntas parecem ser afirmativas.

O tempo histórico do livro de artista é o nosso tempo de certezas rasas. Afirma-se, ainda, a restrição, a oposição. "O Belo é expressão do Verdadeiro”, confirma Abraham Moles. "Mas a função de verdade não passa de uma sensação e a obra de arte é menos verdadeira que as flutuações e os movimentos do real" (Moles, 1994, p.155). Vovelle afirma, segundo ele para horror de seus filhos, que todo domingo ao meio-dia assiste (e gosta) a Mulher-Maravilha na televisão."Minhas pesquisas sobre as mentalidades e as representações coletivas diante da morte levaram-me a não negligenciar essas miudezas das expressões do imaginário de uma época, que hoje se traduzem na HQe nas séries de televisão nelas inspiradas, como antes nas imagens e na literatura popular." (Vovelle, p.397). Limites podem ser muito fluidos. No polimorfismo mutante das narrações intermidiais que a arte e a comunicação nos oferecem, pode ser encontrado o desafio do questionamento do gosto. Discutir o kitsch não é o propósito deste exercício. Mas lembremos a constatação de João Adolfo Hansen: "Pós-moderno é o tempo em que
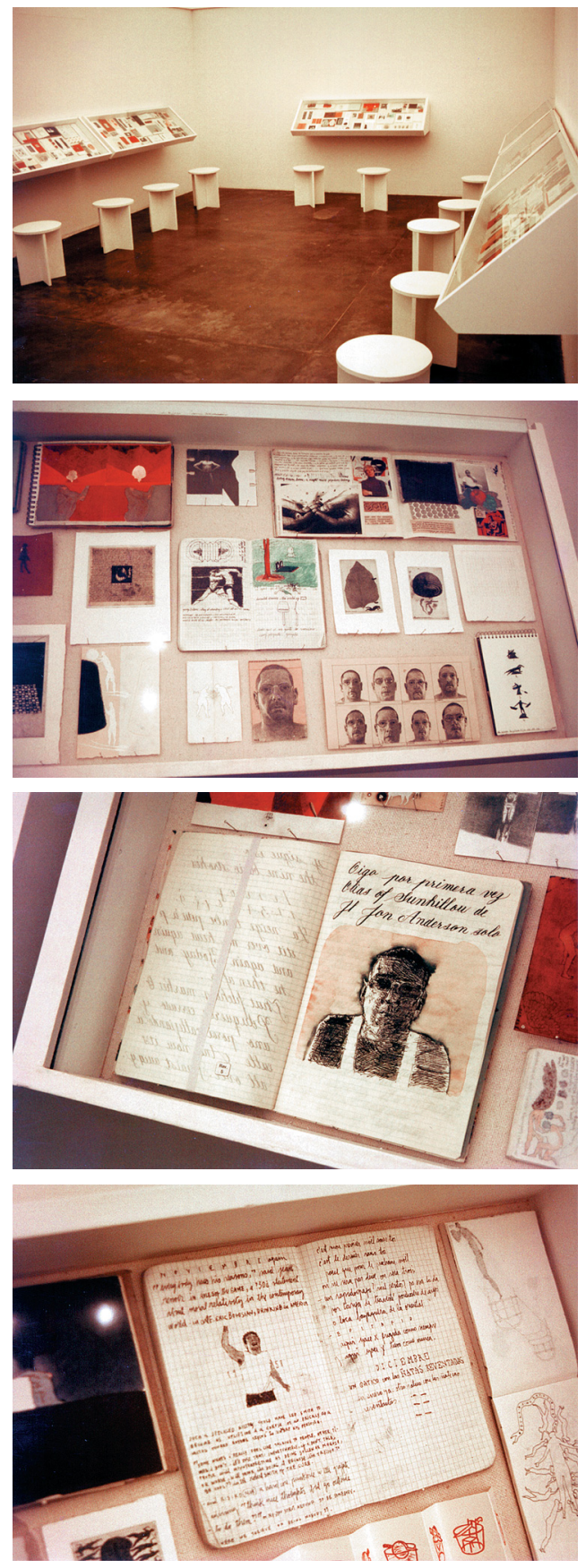

José Antonio Suárez, sala especial com cadernos, XXIV Bienal de São Paulo, 1998. 
aparentemente o kitsch deixa de existir, porque não há critério que se oponha a ele e o negue; no pós moderno, o kitsch é geral, ou nada é kitsch". (Chalhub, p.62.)

"A História é histérica: ela só se constitui se a olhamos - e para olhá-la é preciso estar excluído dela", nos afirmou Roland Barthes em $A$ câmara clara. Ele não acreditava possível a percepção histórica a partir de si próprio: "para mim, a História é isso, o tempo em que minha mãe viveu antes de mim [grifo do autor]". Barthes reposicionava, assim, o papel da visão fotográfica, agregando como valor à fotografia a função plena do dado subjetivo pessoal. Lucia Santaella em seu artigo "Pós-moderno \& semiótica" (Chalhub, 1994) defende sua preferência pela designação "pós-modernidade" e sua ligação com os conceitos de era e limiar. A indefinição desse momento provocaria o problema do descompromisso ético e distúrbio narcísico: "se os antigos valores ruíram e a realidade não se estabiliza num perfil definido, que cada um se encapsule na esfera de seu mundo próprio, embevecido diante de um espelho intocável pelas máculas do real". Está aí um dado ligado ao sujeito que pode contribuir para a necessidade de exposição da realidade
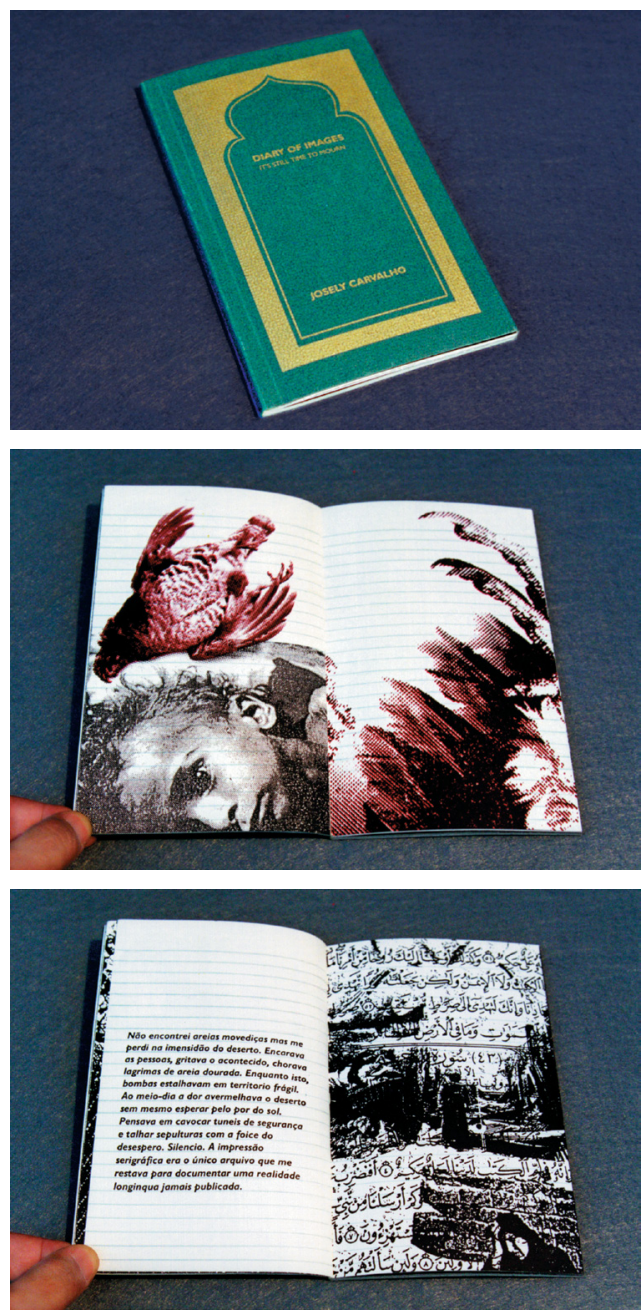

Josely Carvalho,

Diary of images: it's still time to mourn, 1992, íntima, seus fatos e ambiguidades. Santaella lembra que a pós-modernidade frequentemente se sobrepõe ao modernismo. É a "era da informática, da telemática, pós-cultura de massas”, etc. A marca da pós-modernidade seria, então, identificada com a revolução eletrônica. Mas se a modernidade codificou as cinco belas-artes visuais em desenho, pintura, gravura, escultura e arquitetura, não seria justo considerarmos as novas categorias intermidiais (mesmo sabendo de sua gradual evolução através do século) como mais ou menos contemporâneas das mudanças econômicas, políticas, tecnológicas e intelectuais mais recentes?

Os elementos condicionantes do cruzamento entre a história social da arte e as variáveis psicológicas do artista requerem reflexões sobre as categorias tradicionais da expressão artística, que não são exatamente o propósito desse trabalho. Já o livro de artista é certamente uma mídia artística algo marginal. Dentro da linha de tempo dos 
últimos vinte ou trinta anos, ele pode exibir uma amostragem de eventos maliciosamente inseridos nos quesitos tradição e ruptura. Não somente morfológica, mas também semântica. A arte do século 20 consagra um espaço especial para a presença do documento pessoal, como colagem, no princípio do século, e como citação, no final. Uma presença eloquente, por vezes excessiva, rocambólica, que também se apresenta como elemento de linguagem, além da mera relação texto, imagem e coleção. É, portanto, necessário localizar ou identificar alguns exemplos dessa ocorrência documental na produção contemporânea também nos livros de artistas, já que sob certas circunstâncias, o registro da intimidade do artista e de seu mundo em um livro-obra pode produzir um grau de estranhamento diverso da emoção propiciada por um simples diário com colagens. Naturalmente, isso gerará reflexões adicionais. É o momento em que o registro ou o vestígio plástico subverterá a integridade literária que se presume característica do livro comum, e "atestará" a singularidade íntima de uma personalidade artística.

Persiste a memória, como persiste a evidência da continuidade (e certo sucesso) dos discursos egocêntricos sobre suportes inicialmente previstos para propostas socializadoras. Examinando-se com atenção os catálogos de Printed Matter dos últimos cinco anos e confrontando-os com o de 1986 (comemorativo dos dez anos do espaço), tem-se a manutenção tanto da premissa conceitual como do produto romântico. Mas a primeira parece passar a ser, digamos, menos pura, lentamente oferecendo maior território para uma comunhão entre propostas. Há quem aponte essa convivência como evento inserido na pós-modernidade. Brian Wallis, especialmente, no ensaio “The artist's book and postmodernism" localiza uma ocorrência tipo em 1980, no livro Autobiography, de Sol LeWitt. Ele mantém os princípios sequenciais e as tramas rígidas, reminiscências dos seus treze trabalhos anteriores e recorrência de uma parcela importante das obras conceituais. Mas agora o trabalho é executado pela justaposição de fotografias em 126 páginas com grades de nove fotos cada. As imagens foram obtidas de seu loft em Manhattan. "Como uma autobiografia, esse arquivo registra não o ateliê alquímico de um artista genial, mas os componentes fragmentados de um cotidiano individual". Wallis prossegue:

Em outras palavras, com a apropriação brincalhona de dois gêneros - autobiografia e livro de artista - LeWitt inadvertidamente levantou um problema que se tornaria central ao pós-modernismo: o relacionamento entre texto e imagem. [...] A Autobiography de LeWitt toca em três aspectos-chave do pós-modernismo: a fragmentação da subjetividade, a introdução de novas formas de narrativa e as determinações espaciais da ação política na mudança da crítica privada para a pública. (Lauf e Phillpot, 1998, p.93)

Wallis está falando do livro de artista no sentido estrito, que permaneceria vivo e com significado político renovado, ao contrário do pessimismo de outros comentaristas. $\mathrm{E}$ teria, por isso, correta inserção no tempo histórico, quer social, quer artístico. 


\section{Memória e documento pela escolha da forma códice}

Aceitemos, como exercício de pensamento, a bem-humorada afirmação de Charles Jencks, muito divulgada, em que o fim da arquitetura modernista se deu em 15 de julho de 1972, às 15h32min, data da implosão de um projeto habitacional de Saint Louis, construído por Minoru Yamasaki, exemplo de funcionalismo modernista e detestado por seus habitantes. ${ }^{13}$ Usando como baliza o período de tempo em que essa data está inserida, fazendo parte do mesmo contexto sócio-histórico onde estão as experiências intermidiais, poderíamos aqui propor uma amostragem dos eventos de ruptura e/ou manutenção das tradições pelos novos suportes. Penso que a categoria mais aquinhoada de contradições seja a do livro de artista contemporâneo, que dentre as suas possibilidades expressivas foi contenedor de documentos ou se fez como tal. Seu vínculo com a tradição do códice tem sido seu orgulho e seu tormento. Ao mesmo tempo que a conformação tradicional facilita sua comercialização, transporte e estocagem (estou falando em obras múltiplas em offset ou outras técnicas de reprodução), ela obriga a soluções criativas que transponham suas limitações. Por outro lado, a produção de uma peça única é mais acessível ao artista.

Com frequência, o livro de artista é veículo para exercícios com sua própria identidade: comentários sobre o pastiche, o compósito, o kitsch, o retrô, o futurístico. Ele se apropria de enredos preexistentes, une elementos visuais díspares, finge ser o que não é, se apodera de outras formas gráficas (quadrinhos, almanaques, fotonovelas, etc.). Quanto à citação, seja visual, seja locucionária, ela é tão comum que muitas vezes não discernimos o autêntico, ou sabemos se ele realmente importa. Especialmente nos anos 80 e 90 os artistas têm-se apropriado da verdade, utilizando desde as técnicas tradicionais de encadernação, agora recicladas, até as possibilidades da informática para mover um carrossel que vai das formas pré-livro até as formas pós-livro (book based), passando pelo discurso do não-livro.

Vejamos a presença plástica do registro e do testemunho. Ele aparece de muitas formas, já que o meio parece ter postura confessional por natureza, além de possuir uma característica aura de fetichismo, possivelmente herdada do livro tradicional tanto quanto do objeto artístico. Também o impor-se como verdade é usual (uma colega pesquisadora me disse certa vez que tinha a propensão a acreditar em toda palavra impressa como expressão da verdade).

A primeira maneira do documento se instaurar no livro (ou o inverso), é a que o faz conformar-se no tipo relato visual ou catálogo. Não devemos confundir com os catálogos convencionais, que são uma dissertação gráfica sobre um artista ou uma exposição. Trata-se aqui de uma peça ímpar, concebida pelo autor, que acompanha ou prolonga

\footnotetext{
${ }^{13}$ Citado por João Adolfo Hansen no seu artigo “Pós-moderno \& cultura”, em Chalhub, 1994, p.66.
} 
uma atitude. É o registro histórico de algum tipo de atividade plástica do artista, performática ou não, que pode existir sozinha ou acompanhada de outras formas. É uma aproximação externa, às vezes convencional quanto à forma, e já bastante frequente nas vanguardas do século 20 , como o futurismo, o surrealismo e o construtivismo e suas variações. Não há necessidade de maiores comentários, já que normalmente pouco denuncia (como confissão) da intimidade do criador. Este momento desta pesquisa se interessa pela verdade ou pela verossimilhança na revelação da intimidade real ou "construída". Apenas cito como exemplo (já deixando de ser recente) os diversos trabalhos do grupo (ou movimento) Fluxus.

Também há algo de exterioridade nos livros formados por coleção documental a partir de algum tipo de coleta que representa uma experiência vivencial. Nesse caso o artista elege sua atitude entre o caminho do acaso (aquilo que casualmente ou incidentalmente chegar a ele numa determinada situação) ou de algum princípio norteador (uma norma específica de coleta). É o que acontece, por exemplo, com o trabalho

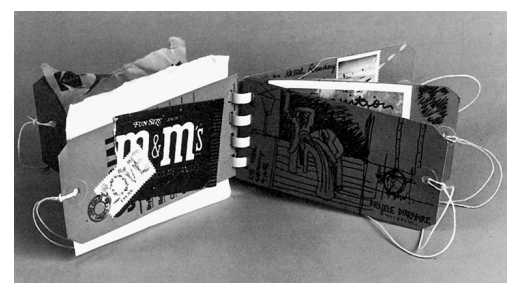

Sas Colby, Souvenir of Documenta 7, 1982 (Moeglin-Delcroix, 1985, p.137).

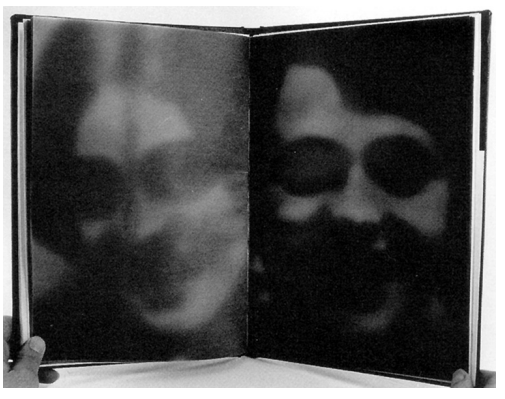

Christian Boltanski, Classe terminale du Lycée Chases, 1987 (Drucker, 1995, p.329). Souvenir of Documenta 7, de Sas Colby, 1982, formado por souvenirs, papéis amassados, embalagens, desenhos, fotos, etc., agregados em um pequeno volume, ou com Classe terminale du Lycée Chases, de Christian Boltanski, 1987, organizado a partir de fotos de estudantes extraídas do anuário de uma escola judaica durante a Segunda Guerra. O evento denunciado ou que ocorreu com o artista, ou ao qual ele se refere, pode ser "remontado" a partir de seus indícios.

Mas nos interessa, neste momento, verificar a opção de alguns artistas pelo aparentemente convencional. Em primeiro lugar, a utilização zelosa da brochura comum, que apela para a grande distribuição, principalmente naquelas obras que eu chamaria de esclarecedoras, reveladoras, obscenas porque desveladoras e denunciatórias da vida pessoal do artista ou de seu entorno, de uma forma direta, sem pudores. Em segundo lugar, o caso dos cadernos e dos livros de notas reais ou simulados, utilizados por artistas plásticos como complemento de sua vida profissional ou afetiva. No primeiro caso temos o real e/ou o imaginário depositados em uma forma da qual, afinal de contas, também se espera a ficção. Além disso, o artista traz para a arte uma conformação gráfica que pode ser considerada por alguns estranha a ela. No segundo caso podemos ter o que o artista quiser, mas, presumimos, em território "real", vestigial, não em cenografia. Ele movimenta para o mercado artístico o que provavelmente é (ou ao menos parece ser) um conjunto de notas e esboços pessoais (íntimos), agregando valor ao seu pré-produto. 
A expectativa de veracidade trafega, assim, da "mensagem" para o suporte e vice-versa.

Johanna Drucker (1995), ressalta as vertentes que surgem depois do pós-guerra, como o letrismo, o Fluxus, a pop art, o conceitualismo, o minimalismo, o movimento artístico feminino (ou feminista) e o pós-modernismo, até as correntes atuais do multiculturalismo (a autora não define precisamente esse termo). Ela não se detém no estudo dessas vertentes, o que nos priva de suas opinióes sobre o livro de artista na pós-modernidade ou perante o multiculturalismo. A mesma omissão acontece com o livro-objeto, não enfocado por opção pessoal, pela preferência da autora pelas obras reproduzíveis (Drucker faz queixas de alguns autores, ou porque não seriam suficientemente contemporâneos, ou porque supervalorizariam o livro escultórico). Mas um capítulo é dedicado ao livro de artista como documento. A palavra "documento" é aqui usada em seu sentido mais objetivo, material, entre o histórico e o antropológico, mais do que no sentido psicológico. Ela busca demonstrar a capacidade natural dos livros em exercer essa função. Drucker os classifica em cinco grupos: enunciados pessoais e de diários (o grupo maior), registros reproduzidos (reais ou inventados), documentos fac-similados, livros de informação (compostos de material denotativo) e documento real (o oposto da reprodução, com o registro físico verdadeiro, como manchas ou outros sinais, por exemplo, cuja ocorrência documenta o documento ele mesmo). Do primeiro grupo de exemplos que ela rapidamente cita, gostaria de, mais adiante, desenvolver um pouco mais sobre Difficulty Swallowing, de Matthew Geller, 1981. No momento, apenas acrescentaria que, obviamente, esses grupos se interpenetram com as obras apresentando características simultâneas.

\section{Exacerbação documental: passionalidade versus contrição}

Um exemplo de overdose de documentação pode ser demonstrado no, com ou pelo livro Autobiographies, de Richard Kostelanetz, 1975. No presente caso, estou trabalhando com a edição de 1981. O autor não é propriamente um artista plástico. É um poeta visual de atuação na comunidade cultural americana, onde construiu sua influência na literatura, na poesia e na crítica, assim como áudio, vídeo e outras mídias. É autor de muitos artigos e ensaios. Na literatura visual, gosta de trabalhar com a desconstrução da linguagem, como ele próprio afirma.

Autobiographies é um livro aparentemente simples. É uma brochura de papel comum, com lombada colada, sem orelhas, integralmente impresso em uma cor (preto), impressão offset, formato vertical de $21,5 \times 14,0 \mathrm{~cm}$, com 288 páginas. O surpreendente é a sua ego trip. A quantidade de "provas" do que está sendo afirmado é enorme. O maior volume de material é de texto tipográfico, mas também há desenhos, reproduções de documentos, depoimentos, exercícios de poesia concreta e um material que parece ser inesgotável. Há uma autoentrevista, uma autocronologia, pesos e medidas de suas primeiras semanas de vida. Somos informados que seu primeiro sorriso foi com 
três semanas ou que ele é razoavelmente sofisticado nas práticas heterossexuais. São registradas todas as suas publicações, bem como todos os trabalhos não publicados. Ficamos sabendo do que ele gosta ou não gosta, de alimentos a artistas e pensadores. Há uma inacreditável lista de todas as mulheres que tiveram relações sexuais, em duas subdivisões. A primeira detalha os motivos dos parceiros ("BR dormiu comigo porque achou que iríamos casar... Eu dormi com BS porque ela me lembrava uma mulher de Modigliani... PW dormiu comigo porque, como uma editora iniciante, ela queria conhecer melhor os escritores... Eu dormi com MW porque ela me pareceu brilhante e rica..."). A lista "II" é sintética e codificada e apresenta a invejável marca de 125 parceiras, segundo Kostelanetz "pessoas tão reais quanto o autor":

$$
\begin{aligned}
& \text { E.B., 15, J, S, 18, M, B. } \\
& \text { B.R., 21, P S, 4, L, C. } \\
& \text { A.L.T., 20, P, S, 450, L, C. } \\
& \text { C.T., 18, P, S, 30, D, B. } \\
& \text { B.S., 22, J, S, 50, L, B. } \\
& \text { E.A.F., 22, F; S, 50, L, B. } \\
& \text { N.W., 23, J, S, 15, L, B. } \\
& \text { P.W., 23, J, S, 1, L, B. } \\
& \text { J.S., 24, J, S, 105, L, B. } \\
& \text { R.J.M., 37, J, D, 6, L, B. } \\
& \text { [...] }
\end{aligned}
$$
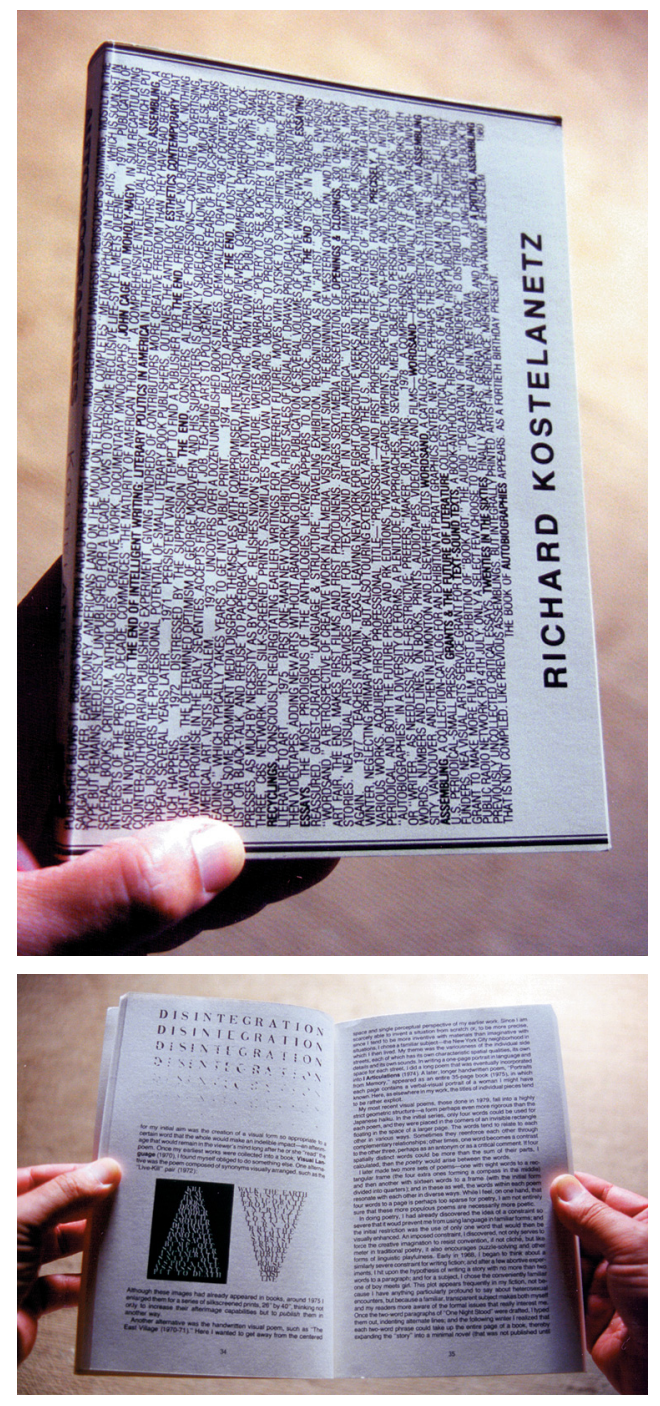

Richard Kostelanetz, Autobiographies, 1981.

Também apresenta reprodução de poemas concretos, testes vocacionais, ficha para encontros por computador, desenhos, descrição de atividades diárias, exercícios de assinatura (!), confissões e o que mais se puder imaginar. Como se não só declarações, enunciados e imagens bastassem, Kostelanetz ainda inclui, por convite, os testemunhos de alguns amigos. A marcação do tempo se dá pelo tradicional: as páginas são numeradas como o usual (com fólio) e há datas (muitas datas) em todo momento. Pouco antes do final (por que não?), os obituários de suas mortes de 14 de novembro de 1960, 15 de maio de 1970 e 15 de maio de 1980.

O exemplo do livro de Kostelanetz, enunciatório, guarda uma certa elegância, cujo bom humor e aspecto modesto só faz ressaltar. 
Caberia, agora, examinar um outro exercício testemunhal, também apoiado no vestígio (entendido como sendo aquilo que sobra de um evento ou que dele é resultado).

A surpresa que causa Difficulty Swallowing, de Matthew Geller, é fruto de uma sensação estranha, que se confunde entre emoções ensaiadas e o drama verdadeiro. Também essa é uma brochura comum, em impressão offset, preto-e-branco. Apenas a capa possui cor: uma impressão em verde e textos em letras douradas. $\mathrm{O}$ formato é um pouco maior, $25,5 \times 17,2 \mathrm{~cm}$, tamanho determinado pela sua proposta. Geller acompanhou sua namorada Elley no hospital, também artista plástica, a partir de março de 1979, para tratamento quimioterápico de leucemia. Numa primeira impressão lembramos do gosto tradicional médio norte-americano pelos apelos sentimentais tão frequentes em revistas, cinema e televisão. Mas será que se trata disso?

O livro possui um prefácio, o único momento na primeira pessoa do singular:

Quando era muito jovem, eu odiava ir ao médico receber injeções. Eu começava a chorar quando o doutor deixava a sala para buscar a seringa. Queria crescer para me tornar imune a esse medo.

O primeiro país estrangeiro que visitei foi o México. Eu conhecia suficiente espanhol para ler um cardápio. Mas quando fui a um restaurante e o garçom perguntou sobre meu pedido, eu compreendi que não sabia como pedir.

Numa aula de biologia no colégio, tive que dissecar uma rã viva. Espetei a rã, barriga para cima, numa bandeja com cera. Rangendo meus dentes, fiz a primeira incisão. Quando removi a pele, pela primeira vez enxerguei um coração batendo e pulmões se expandindo.

A primeira vez que vi Elley, ela estava soldando sua escultura. Parei por um momento observando-a no seu trabalho. Então me apresentei e perguntei se ela gostaria de tomar uma cerveja.

M.G.

New York, abril de 1981 
Aqui o relato não é mais sobre si mesmo, e sim sobre outra pessoa, uma pessoa rigorosamente verdadeira. $\mathrm{O}$ artista depõe sobre alguém real inteiramente através de dados também reais. $\mathrm{O}$ trabalho de Geller é comovente. É construído quase integralmente pela reprodução de documentos hospitalares: fichas dos enfermeiros, relatórios médicos, resultados de laboratório. $\mathrm{Na}$ introdução há diagramas de como se ler as notas dos enfermeiros e os prontuários médicos, além de uma lista de abreviações e símbolos. Aprendemos que T 98 significa que a temperatura é de 98 graus Fahrenheit, ou que AML significa acute myelogenous leukemia. Muitos nomes foram trocados ou obliterados, dependendo da vontade do envolvido. O que realmente lemos são os registros, diretamente e sem intermediações. Reconstituímos a totalidade pelo exame de seus fragmentos. Os fac-símiles são acompanhados por alguns desenhos, como da disposição dos móveis no quarto ou das alas do hospital, e por trechos de um diário. Muitas páginas são atravessadas pela linha de temperatura de Elley. A sobrecarga de documentos gera um ambiente opressivo e ilusoriamente frio. Existem pouquíssimas fotos, algumas vezes centralizadas individualmente em páginas ímpares, outras vezes confrontadas com uma foto complementar na
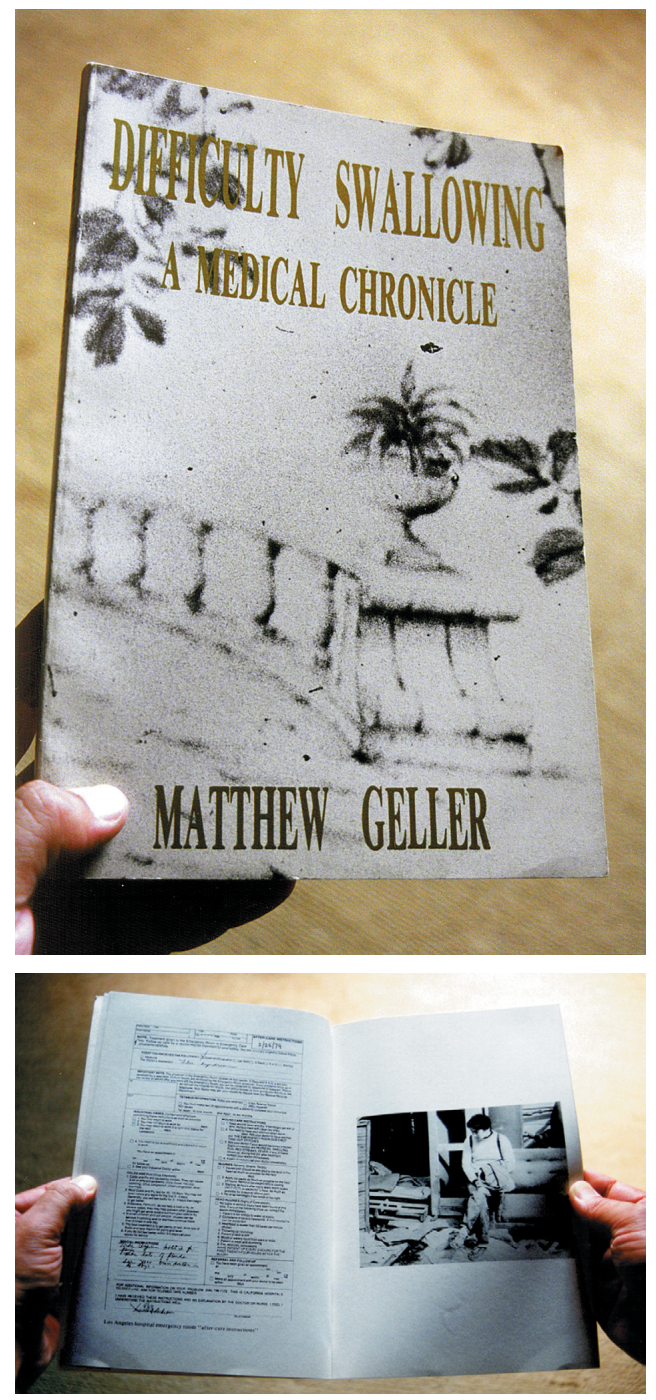

Matthew Geller, Difficulty Swallowing, 1981. página par imediatamente anterior. São ilhas de meio-tom dentro de um universo de brancos. Quando alguma foto aparece é como se respirássemos de novo, ainda que para chocarmo-nos com a humanidade de Elley. O final está prenunciado. Apesar da expectativa, ou por causa dela, nos comovemos profundamente. Comoção, essa, que é causada pela leitura de documentos profissionais. Seria fora de moda dizer que esta é uma obra pungente?

Em Difficulty Swallowing as temporalidades se dão integralmente, sem a necessidade de metáforas ou ilustrações. Uma saudade se constrói pela apresentação da prova de uma existência. Está terrivelmente situado entre o álbum de recordações e o prontuário 

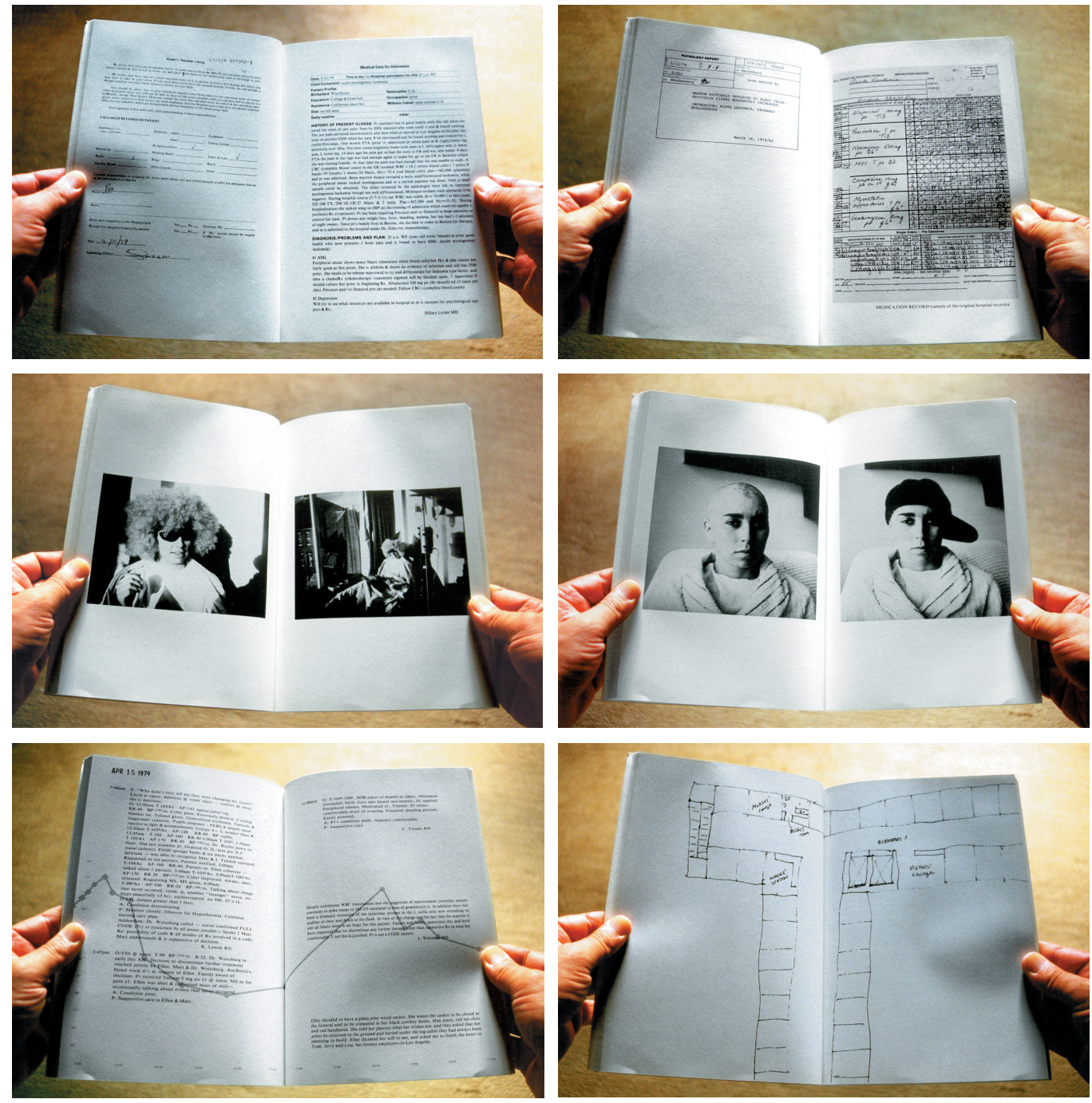

Matthew Geller, Difficulty Swallowing, 1981.

médico. A prova do fato reconstrói o sentido. O ser está contido no objeto. Sentimos Elley, sabemos Elley.

Podemos nos surpreender, quase como arqueólogos, com a possibilidade potencializada da leitura de vestígios. A pista, o sinal ainda se intromete em nossa arte. Talvez com um significado metabolizado. O vulgar pode ser invulgar. Queremos os sinais de nossas existências. Queremos as pegadas. Hoje, anos 90, o relógio parece que anda por gingados. Não para, é certo, mas apenas ilustra um de tantos tempos possíveis. A virtualidade do pixel, integrada em nossas vidas, transmutou-se em outra realidade, difícil de medir por unidades de tempo e espaço, mas transformando todo papel em documento. Esta página que está sendo lida agora, no exato momento em que eu esteja, quem sabe, tomando café, não passa do registro gráfico de uma ação originalmente 
eletrônica. Ela não passa, enfim, de ser o documento último de meu exercício ao computador. E, portanto, apascenta tempos.

\section{Presunção de verdade e verossimilhança}

Mas e se o vestígio é falso é lícito que ele se apresente como documento? A palavra documento presume o registro, a prova ou o testemunho da verdade. Presume a comprovação de uma realidade acontecida no tempo cronológico. Presume datação e fé (civil ou religiosa). Fé ${ }^{14}$ é a crença religiosa em uma realidade não documentada, ou documentada por provas baseadas na própria crença. Trata-se aqui de um círculo. É dizer que algo é... porque é. É a asseveração de um fato, presumindo-se que seja realmente um fato. Se a fé não pede provas, ela causa danos ou impedimentos à ciência. Ela elimina o fundamento para a investigação por eliminar a dúvida. A apresentação da imagem deixa de ter função documental de ilustração e passa a ser, ela própria (a apresentação), ficção. Essa apresentação funda, no livro de artista, a possibilidade expressiva de ser simulacro.

Talvez pinçando alguns elementos relacionados com a expressão da verdade nas artes visuais, possamos nos aproximar melhor do limite entre o sujeito real e o sujeito inventado. $\mathrm{O}$ contributo interdisciplinar é fundamental ao estudo de processos artísticos intermidiais, o livro de artista no presente caso. A partir daqui, o problema passa a dizer respeito especificamente aos diários e cadernos de esboços (ou notas), quando elevados à categoria de obra autônoma ou quando elaborados intencionalmente com esse propósito.

Podemos perguntar que espécie de verdade pode ser encontrada em um caderno de esboços ou caderno de notas, e que dano ao conhecimento da biografia do artista a ficcionalização de suas memórias pode causar. Isso pode implicar ferimento no grau de valor que tem o diário de um artista como documento para o pesquisador ou como obra para o público. Afinal, existem diferentes graus de espontaneidade e verdade nos diferentes tipos de diário de artista. Mas, afinal, que é verdade plástica?

A resposta pode estar em nova pergunta: será que queremos a realidade, ou queremos a ficção? No mundo do entretenimento, pelo menos em suas manifestações mais tradicionais, essa pergunta é um lugar-comum. Um publicitário, por exemplo, sabe que uma foto de um relógio dentro de um aquário "prova" que ele funciona até embaixo da água. Mas parece que a postura popular frente às expressões visuais têm alguma preocupação (talvez com algum desprezo) por simulacros ou personagens forjadas. Lembremos a polêmica no lançamento e primeira fase de exibição do filme de Bruno Barreto, O que é isso companheiro?, 1997. Na época, poderia-se ter discutido sobre os

\footnotetext{
${ }^{14}$ Utilizo a definição vulgar e corrente, sem pretender discussões mais profundas. Conferir os diversos dicionários da língua portuguesa já consultados, em especial os mais antigos e prolixos. Embora o Novo dicionário Aurélio da lingua portuguesa seja considerado uma referência usual em nosso idioma, de novo, aqui, ele se mostra insuficiente.
} 
valores estéticos que ele tinha ou não. Mas quase somente se acusava o filme (e era de fato uma acusação) de não reproduzir a verdade dos fatos, embora (ou porque) para um olhar estrangeiro a história contada fosse verossímil. No cinema, a inverossimilhança não é aceita pelo público, mesmo o intelectualizado.

Espera-se que a obra (e parece que nessa palavra há uma forte conotação artesanal) "espelhe" os mais puros sentimentos de seu autor, que seja o retrato de sua individualidade, que comente as suas mais sinceras opiniões. Que seja, enfim, a verdade através da imagem. Essa afirmação se pretende quase um truísmo. Está entranhada na tradição cultural ocidental. "Ver para crer". É repetida ao infinito por peças de comunicação, pela literatura, pela escola. A publicidade, por exemplo (e com confirmação através de pesquisas e estudos), ${ }^{15}$ sabe da forte associação que o público faz da imagem com a veracidade, mantendo a palavra em plano quase acessório. À imagem é atribuído o valor testemunhal. A imagem é a prova. A publicidade e seus profissionais afirmam que o público quer acreditar. Apesar de tudo, a verdade é tida como um direito do homem que, por sua vez, também projeta em suas leituras as próprias crenças. A desilusão é um ferimento. Melhor não ver: "o que os olhos não veem, o coração não sente". A desilusão é uma injúria.

Como parênteses, volto a Barthes, em $A$ câmara clara. Nenhuma peça escrita pode dar certeza da verdade, mesmo que invoque a ciência da lógica ou o dispositivo do juramento (p.128). É da natureza da linguagem ser ficcional. Para Barthes "o infortúnio (mas também, talvez, a volúpia) da linguagem é não poder autenticar-se a si mesma". Para ele, a fotografia é, essencialmente, "a própria autenticação". Introduziu na família das imagens um "certificado de presença”. Por extensão, estaria a imagem, novamente ela, pela formação de par com a linguagem escrita, assumindo o papel positivo que lhe tem sido atribuído? Ou em outras palavras, que grau de sentimento de verdade ou enunciações positivas pode ser obtido da sobreposição do texto escrito e da imagem?

Existe um recurso utilizado no ensino elementar de alguns países, nas classes de artes, para fazer os alunos trabalharem em projetos que solicitam a sua atenção por intervalos de tempo maiores, ou que sejam continuados de uma disciplina para outra, e, sobretudo, estimulem o hábito da leitura (Book..., 1991). Trata-se da execução artesanal de um livro-objeto, à maneira do livro tradicional mas com profusão de colagens e desenhos. Quanto ao tema escolhido (quando não se trata de assuntos de outras matérias), predomina a autobiografia visual, o que seduz o aluno pela possibilidade de falar de si próprio enquanto executa um trabalho com um novo grau de complexidade. Também a autobiografia é utilizada amplamente nas classes de encadernação criativa em espaços

\footnotetext{
${ }^{15}$ Não é interesse deste trabalho percorrer conceitos e técnicas da publicidade. Entretanto, para outras informações a esse respeito, pode ser feita uma consulta ao livro tão interessante quanto divertido do publicitário e professor Roberto Menna Barreto, Criatividade em propaganda (Rio de Janeiro: Documentário; São Paulo: Summus, s.d., 2.ed.), primeira edição de 1978. Ver especialmente o capítulo "Criatividade visual", subtítulo "Princípio básico: deixe-os ver para crer". Na página 190, com ironia, cita Goebbels: "As pessoas têm propensão imensa para acreditar. Elas precisam e estão sempre prontas a acreditar em tudo."
} 
alternativos de criação para jovens e adultos. ${ }^{16}$ Mas observemos que todos esses casos se baseiam na construção (ou a reconstrução) da tradução do real, da experiência verdadeiramente vivida.

O gênero (ou a técnica) do livro ilustrado, a partir do século 19, e principalmente do livro de artista a partir da Segunda Guerra, pressupõe uma intencionalidade, um projeto. Intencionalidade tanto mais clara quanto mais perto das obras conceituais. Annateresa Fabris e Cacilda Teixeira da Costa (1985) lembram o papel do conceito e do processo intelectual, desenvolvidos "no registro e na 'exposição pública' dos procedimentos do fazer arte", referindo-se aos livros de artista em geral produzidos a partir dos anos 60. Entretanto, seu sucesso nos anos 80, ao menos na Europa e nos Estados Unidos, provocou no valor documental de toda sorte de registros uma transformação crítica que ampliaria ainda mais a variedade de suportes à disposição. Croquis, rascunhos, pequenos textos, desenhos, recortes, ou o que fosse, quando unidos em algum tipo de sequência perceptível, propiciando a constatação do tempo, da memória e do pensamento, formando um novo todo na forma de livro, agenda ou caderno (mesmo que de maneira muito sutil), geraram uma especialização do livro de artista, à imagem e semelhança das agendas e diários pessoais. Essa peça poderia se manter única, um testemunho arqueológico da criatividade. Portanto, para poucos, fechada em gavetas, egoísta e cara. Ou poderia ser fac-similada, apoiada nos novos recursos das artes gráficas industriais. Portanto barata, vulgar, mundana. A individualidade do artista se prometeria de todo, mas intimamente com o colecionador, ou se democratizaria nas mãos de quem quer que fosse, concorrendo marginalmente com os veículos de massa. Surgia, então, um novo tema: o segredo e, seu contraponto, a exposição. Exemplo simultâneo dessas duas vertentes são os CadernosLivros (grafados assim mesmo, em justaposição) de Artur Barrio, desenvolvidos a partir de 1966 e que perpassam várias instâncias de consagração e tiragens que vão do um ao $n$. Voltarei a Barrio mais adiante.

Se quero investigar personalidades inseridas no tempo social, e compreendo que na forma do livro o relato tende a ser verossímil, por que não procurar na linha do tempo tornada gráfica a imagem real da história de uma vida? Penso que o autorretratar-se implica a própria busca do seu real. Para o artista, depositar sua biografia numa mídia que inclui o registro iconográfico "fidedigno", a fotografia, além da declaração pessoal impressa, envolve a escultura de muitos tempos. Existe o tempo tornado espiritual pela memória, o tempo tornado visual pelo registro da imagem e mesmo o tempo tornado acústico pelo registro sonoro. Existem os tempos mecânicos, do ler, do examinar, do folhear. Existem os nossos tempos históricos, o meu "agora" e o "quando" da elaboração da obra. Talvez seja por isso que os autorretratos bibliomórficos tendam ao formato diarístico, já comentado. Ele resume a tarefa do relato pessoal aos escritos, aos croquis e

\footnotetext{
${ }^{16}$ Ver, por exemplo, os programas de atividades do Center for Book Arts, de Nova York, editados duas ou mais vezes por ano, onde estão descritas as atividades normais para professores e/ou estudantes, as atividades paralelas e os cursos de introdução à encadernação criativa e processos alternativos.
} 
às colagens. É sereno, sim, mas preguiçoso, quem sabe até um pouco onanista, porque se compromete pouco com o social. Mas o tempo narrado pode, sim, permitir um rompimento definitivo com o formato do diário pessoal e simultaneamente ser público e ser ímpar.

Uma autobiografia pode ser reduzida à unidade mínima de representação iconográfica, o retrato, disposto num exercício sistêmico. Por exemplo, a obra holandesa Biografie/Biography 1949-1996, de Hans Eykelboom, é elaborada como uma linha de tempo direta. Em offset preto-e-branco, estão reproduzidas 48 fotos do rosto do artista, a partir de seus primeiros anos, uma após a outra, até o ano da publicação. A inserção social na história se dá com bom humor. A metáfora (ou o indício) é construída pela companhia de fotos de máquinas fotográficas, com o modelo de lançamento do ano correspondente a cada retrato. Como etapa de procedimento, o livro está relacionado com outras atividades de Eykelboom, que começou em 8 de novembro de 1992 um diário fotográfico que se encerrará em 8 de novembro de 2007. Para esse diário, o artista tira até oitenta fotos por dia (mas seis dias por semana).
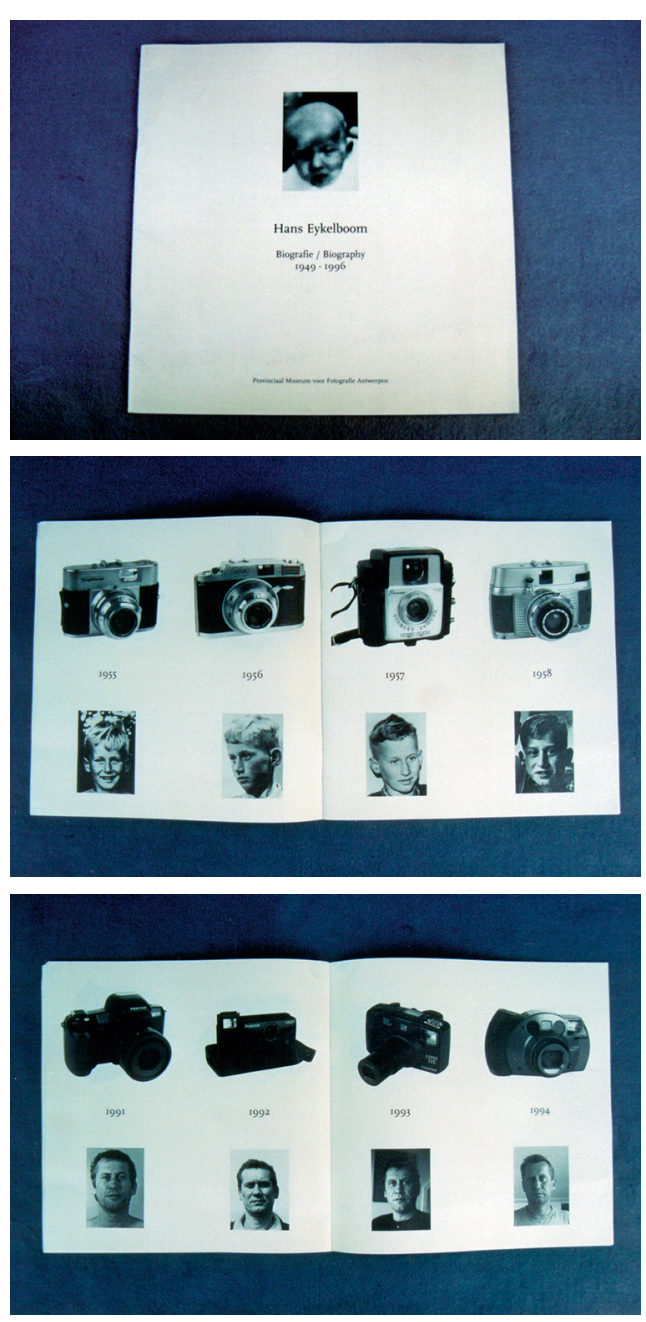

Hans Eykelboom, Biografie/Biography: 1949-1996, 1996. Apesar de tudo, há um certo divórcio da sua intimidade com o público. Nesse caso, os tempos principais são o referido (como assunto) e o sequencial, ambos estreitamente inter-relacionados, já que existe uma ordem cronológica rigorosa.

O Alto retrato, com "1" mesmo, 1981, de Paulo Bruscky, guarda, pelo efeito da fotocópia, a proximidade do autor com o seu público. É um livro alegre e espontâneo, à imagem de seu criador, e herdeiro do aspecto marginal que é companheiro das produções xerográficas dos anos 70 . Tem 160 páginas em brochura formato um pouco menos que $\mathrm{A} 4$, fotocopiadas apenas em um lado. $\mathrm{O}$ registro do tempo passado à obra é feito pela reprodução de fotos de eventos e performances, de documentos do artista e de outras imagens ou textos reproduzíveis. O tempo presente da obra (ou do passado imediato), real ou sugerido, é expresso pelas experiências com a fotocopiadora na reprodução 

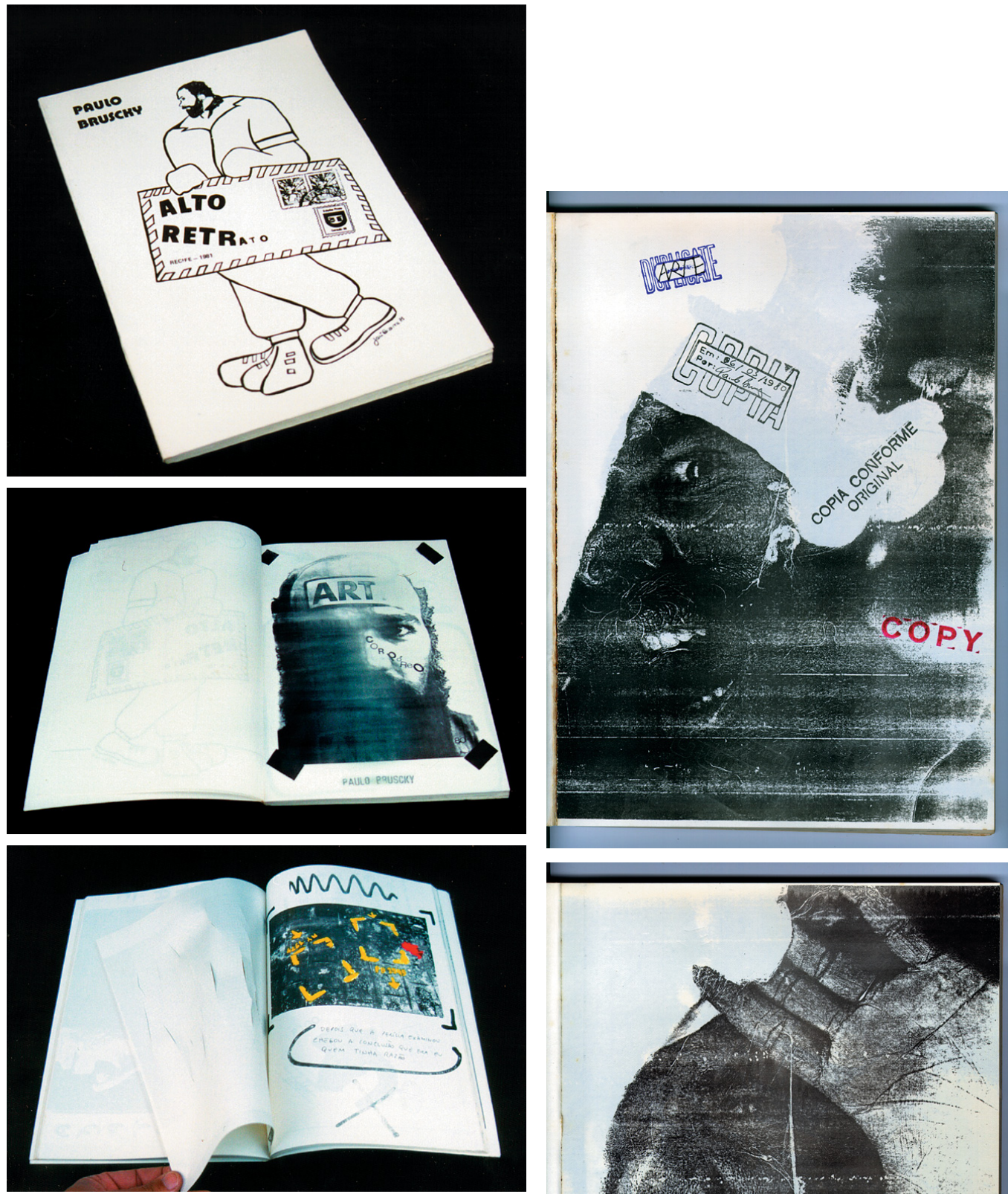

Paulo Bruscky, Alto retrato, 1981.

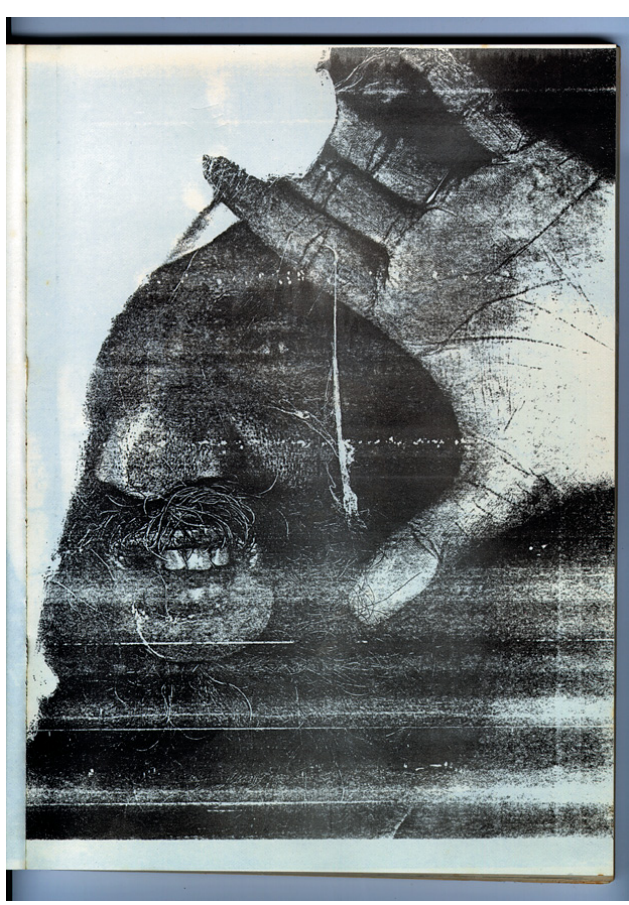


direta do corpo (rosto com caretas). São experiências como a Xeroperformance de 1980, que vivificam o livro pelo comentário ao seu próprio processo. E o tempo imediatamente futuro à obra (mas no passado do nosso manuseio) é dado pelas intervenções gráficas manuais, feitas pelo artista no livro pronto (carimbos, colagens, cortes, furos, riscos, etc.), pouco antes dele chegar às mãos do destinatário. $O$ tempo significativo aqui é o referido como assunto ou como vestígio do processo, e não o sequencial.

\section{Representação do confessional e do lúdico: memória real versus memória emulada}

Antonio Dias lembra da sua "mania de sempre desenhar em pequenos cadernos, onde também registrava ideias, textos autônomos ou simplesmente sequências de imagens. E continua: "tenho cadernos feitos assim desde aquela época, embora não tenha chegado a produzir nenhum deles industrialmente" (depoimento de 1984 para Fabris e Costa, 1985). Com
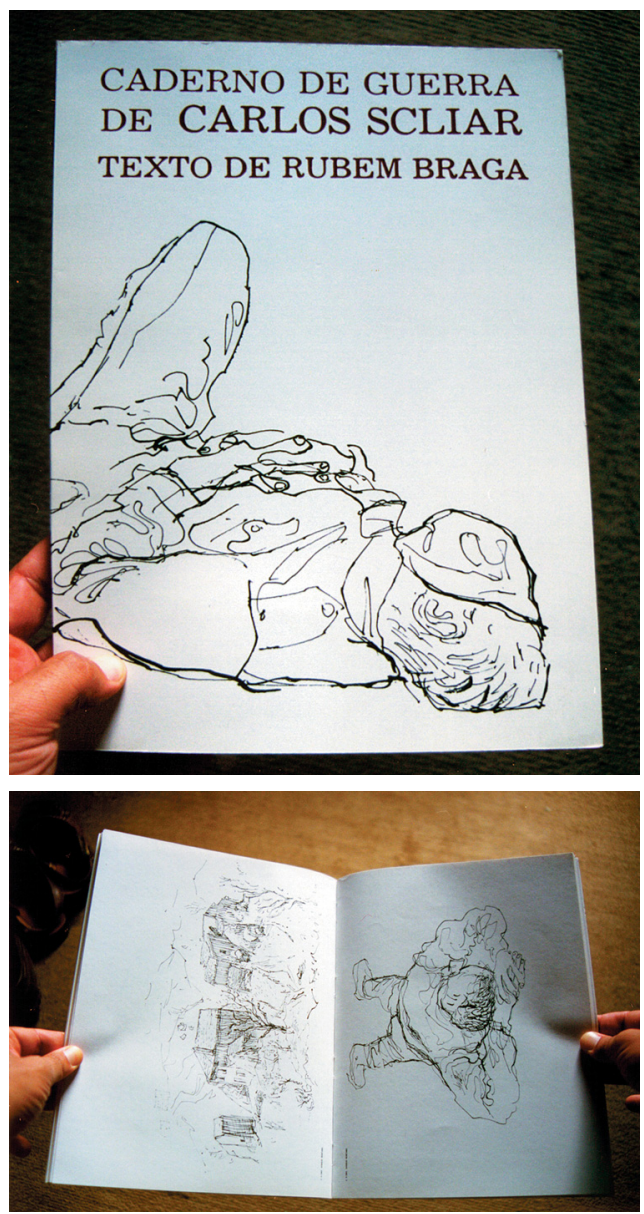

Carlos Scliar,

Caderno de guerra de Carlos Scliar, 1969 (edição fac-similada de 1995). produção industrial, capa em duas impressões e miolo em preto, O caderno de guerra de Carlos Scliar, 1969, ${ }^{17}$ demonstra outra possibilidade de registro da experiência pessoal, através de desenhos. Nesse caso, a anotação é do momento histórico e social. O registro é testemunhal, descritivo de um fato (a guerra), pelo desenho quase jornalístico, de observação, tomado diretamente dos modelos (os soldados brasileiros na Itália). Não existem neles elementos surrealizantes ou simbolistas que possam transmitir ou induzir a uma mensagem confessional ou um juízo. Entretanto, o próprio Scliar ressalva, na edição fac-similar de 1995: "Foram esses desenhos que me salvaram. Todos os dias pareciam os últimos, a tensão era permanente. [...] Sim, tenho certeza que posso classificá-los como desenhos

${ }^{17}$ Caderno de guerra de Carlos Scliar. Com texto de Rubem Braga. São Paulo: Pinacoteca do Estado, 1995. Fac-símile do original de 1969. Tiragem de mil exemplares. 
de salvação!". Apesar da capa e do projeto editorial do volume, realizado 25 anos depois, terem sido realizados pelo próprio Scliar (que também foi um projetista gráfico), a presença do texto de Rubem Braga denuncia um certo grau de formalismo, que reduz um pouco a pureza da experiência visual. A conformação da obra resulta aproximada dos padrões bibliográficos tradicionais.

Um exemplo da subversão de funções do registro pessoal pode ser encontrado no trabalho do francês Roman Opalka, realizado a partir de 1965 . Nele, o bloco de desenho faz parte de uma sistemática maior e em processo, de uma vida. Opalka é um copista. Copista rigoroso de seu próprio projeto pessoal. Seus cadernos (ou blocos) são o fruto do rigor e da autodisciplina. Da continuação de seu ato de pintar (ou grafar) os números de uma contagem a um hipotético e idealizado infinito, ora na tela, ora no papel, o próprio comentário do tempo é autofágico. A possibilidade da história pessoal narrada pelo vernáculo se esvazia pela ideia, que, por sua vez, se alimenta do mecânico (a ação de pintar ou escrever). Ela própria, a ideia, se instaura como ensaio, num espaço - no caso os blocos de desenho - destinado às narrações e dissertações. Pode-se, quando muito, adivinhar linhas gerais de pensamento. Mas não nos é dado acesso à história pessoal de seu autor, no sentido narrativo-descritivo convencionado (literário). Mas o traço autobiográfico está lá, revelador, evidenciado pelo registro de um projeto de vida. Naturalmente, isso fica mais claro com a inserção do bloco de notas no conjunto de sua obra. Nesse caso, ampliam-se as relações conotativas e denotativas pela influência recíproca de suas telas, das fotos de seu rosto envelhecendo e das gravações de sua voz a contar números.

A também francesa Annette Messager é mais explícita na marcação das divisões. Em dois desenhos de 1973 aparece seu pequeno apartamento dividido em quarto e estúdio, definidos respectivamente como os domínios da collectionneuse (colecionadora) e da artiste (artista). Messager, antes de iniciar um corpo de obras, gastou algum tempo ideando-se a si própria como uma artista, segundo artigo de Nancy Princenthal (1995), num processo de tentativa e erro. Essa cisão de identidade foi seguida por outras: Annette Messager truqueuse (malandra, charlatã), femme pratique (mulher prática), colporteuse (mascate). Isso também é notado no livro-catálogo de Anne Moeglin-Delcroix, Livres d'artistes, 1985, em que inclusive Messager, que aparece na seção livros inventários, retorna na seção livros manuscritos. O papel de colecionadora foi o principal responsável pela montagem e organização em álbuns de componentes de uma narrativa pessoal enquadrada em um contexto social, totalizando (entre 1971 e 1974) 56 Album-collections. São livros únicos, 
irônicos, com desenhos originais, manuscritos, fotos alteradas e diferentes anexações, demonstrando exercícios de autodefinição, como o número 2, Os homens que eu amo, o número 5, Meus desenhos de infância, o número 23, Como meus amigos me desenhariam ou o número 24, Minha melhor assinatura. Muitas das imagens que eles contêm foram exibidas independentemente ou reproduzidas, e alguns álbuns, no todo ou em parte, com ou sem modificações, foram reproduzidos fotomecanicamente. Seu primeiro livro em offset ( 75 cópias) contém material (próprio

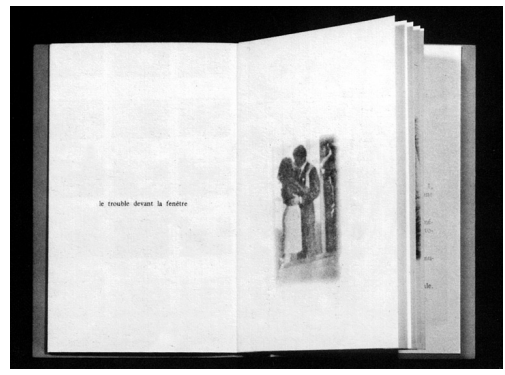

Annette Messager, Mes clichés-témoins, 1973 (Moeglin-Delcroix, 1985, p.78). e coletado) do álbum número38, Mês clichés-témoins (algo como "meus clichês-testemunhas", numa provável, e ambígua, menção à exposição multiplicada por impressão ou por chapas fotográficas).

Os livros atraem "porque eles são muito secretos. No início, eu temia ter algo na parede”, diz Messager em entrevista para Princenthal (op. cit.), que por sua vez complementa que sua (dos livros) intimidade é forjada, uma vez que a mulher que eles coletivamente identificam é, na palavra de Messager, ficcional. Prossegue Princenthal: "Em outras palavras, não é o ambiente dos livros mas seu perjúrio emocional que protege a privacidade da artista" (o grifo é meu; lembro da proximidade conceitual entre perjúrio e injúria).

Messager apresentou, como seu alter ego composto, uma dissimuladora tão cercada por desconfiança e insegurança que sua intensa autodeprecação pareceu uma garantia de sua autenticidade. No delicado equilibrismo de Messager, o assunto do discurso (que é a própria artista) é muito tímido para clamar mesmo por sua própria identidade. $\mathrm{E}$ ao mesmo tempo, ela é corajosa o suficiente para fazer escárnio - ou, ao menos, teoria informal - de tão ostensiva timidez feminina.

Acrescento as palavras de Bernard Marcadé para catálogo distribuído na 21a Bienal Internacional de São Paulo, 1991, a propósito de trabalhos murais apresentados: "Troçando com paixão e recuo de todas as imagens, inclusive das que os outros the remetem dela própria - sucessivamente, midinette e femme fatale, castradora e protetora, feiticeira e exorcista - Annette Messager capta o olhar e o desejo dos outros nas teias aracnídeas de sua arte... Mas nesses jogos e nessas armadilhas ela própria se deixa também prender..."18

É curioso que praticamente não existe fuga do suporte tradicional na execução de registros pessoais. $\mathrm{O}$ mesmo acontece na realização de múltiplos de poucas cópias ou de grandes tiragens fac-similadas. É preservado o formato tradicional de caderno, bloco

\footnotetext{
${ }^{18}$ L'excès $\Xi$ le retrait (ou O excesso $\Xi$ o recesso), catálogo da participação francesa na 21ª Bienal Internacional de São Paulo, 21 de setembro a 10 de dezembro de 1991. Texto de Bernard Marcadé com tradução de Roberto Pontual.
} 
ou livro. A superfície é preservada quase que intacta. Rupturas que possam ter acontecido em outras formas do livro de artista não encontram terreno aqui, onde, parece, a legitimação faz parte do jogo. Manteve-se a tradição: grafismos, escrituras, desenhos, carimbos, colagens e anexações. Enfim, a página como suporte mais ou menos convencional, para os padrões do século 20, é claro.

Retornando às indagações quanto ao valor como verdade informativa do caderno de artista, tenho no artigo de Leo Rubinfien para a revista Artforum de março de 1977 um importante (se não raro) subsídio para essas considerações. Já no primeiro parágrafo o problema nos é colocado de forma clara:

Em teoria, um caderno de esboços não é mais do que o seu nome sugere - um terreno para tentativas preliminares na execução de ideias que podem com o tempo ser descartadas ou podem evoluir constantemente em obras mestras. Como tal, é provavelmente mais privado que público, um registro de fracassos e sucessos rudimentares que são de pouco interesse para qualquer um além do artista responsável por eles, exceto quando nós podemos associá-los a realizações maiores. Naturalmente, o valor de fazer tais ligações tem sido largamente percebido. É usual, se ou não um certo desenho do caderno de esboços realmente precede uma obra famosa, encontrar nos cadernos um amplo e matizado senso do caráter de um artista e o padrão de seu intelecto, e incluí-los em nossa compreensão de seu corpo de trabalho como um todo. Contudo, esboços e anotações ocupam um grupo intermediário entre pensamentos inexpressados, não registrados, e arte pública acabada. Eles não são devedores aos imperativos a que a arte maior é - não é necessário aperfeiçoar um livro de anotações mais do que a prosa em um diário. Declaramos que tais criações não são realmente planejadas para o público e, assim, portanto, nos liberamos para ser extravagantes, hiperbólicos, recherché, melancólicos, imitativos e até mesmo inarticulados, quando nunca nos permitiríamos essa licença perante o público.

Rubinfien lembra que a persona do artista transparece até no mais calculado projeto público, mas que nos cadernos ela é o objeto da obra, algo como uma contrapartida dos artistas visuais ao poema confessional contemporâneo. Apesar de ostensivamente privados, muitos foram feitos com o pensamento na audiência ou mesmo na posteridade. A partir da observação de uma exposição no Philadelphia College of Art (Estados Unidos), Rubinfien pergunta se essa característica seria uma tendência em artistas contemporâneos que mantêm anotações. Ou seja, manter uma exortação na certeza de que haverão ouvintes. A obra poderia ser um mutante intencional de ferramenta autorreflexiva em peça de comunicação. Eu acrescentaria, também: numa peculiar forma de perversão irônica, instrumento compósito de vaidade e marketing pessoal, a altivez e a exacerbação da autoestima, travestida em um relicário conspícuo. A privacidade, pois, deve ser sempre apenas suposta. Ou seja, como prossegue Rubinfien,

[...] mesmo um caderno de esboços, um repositório de segredos e sentimentos anti ou insociais, é preenchido com pose. [...] o gesto real de expressar suas crenças, sentimentos, desejos, sua individualidade, o obriga a assumir a forma de outra pessoa. Essa pessoa pode ser uma ficção original ou uma composição de pessoas admiradas, e com sorte será um caráter afim com seu autor, mas é inevitavelmente uma personalidade talhada ao molde: se o molde é um caderno de espiral de 4 por 6 polegadas ou uma tela de 6 por 12 pés é de importância secundária. 
Mas, no fim, esse produto do exercício criativo e/ou confessional é, de fato, uma interlocução com o outro. Se existe algum dano à apreensão científica do pensamento do homem artista verdadeiro (seja lá o que essa palavra significar), por outro lado existe a coopção terna entre as individualidades do leitor/fruidor e do ser-em-obra. Afinal, é importante o entendimento do gesto que multiplica e distribui o que é (ou o que se esperaria ser) pessoal e privativo. Artur Barrio, que foi mencionado algumas páginas atrás, chamou suas obras desse gênero de "CadernosLivros", o que já apresenta o trabalho como um híbrido entre o confessional e a peça de divulgação. Em seu espaço na 23a Bienal Internacional de São Paulo, 1996, Barrio, que colocou exemplares de seus livros em vitrina - ver mas não tocar-, deixou entre os cristais de sal e seus objetos, para quem pudesse achar, exemplares fac-similados em offset. Esses sim, podiam ser tocados e deviam ser levados para casa pelos visitantes. Uma tiragem provavelmente gigante para os padrões brasileiros, adequada para uma mostra do porte da Bienal, o mais rumoroso
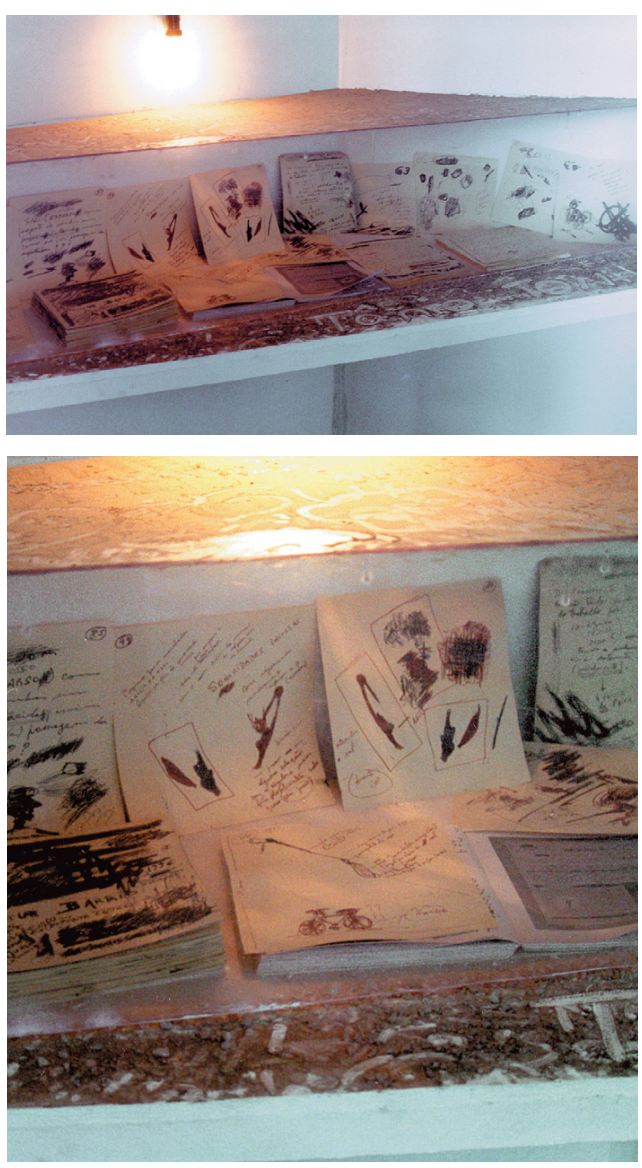

Artur Barrio, vitrina na 23a Bienal de São Paulo, 1996. evento artístico nacional, e injuriante para os que querem guardar distância da divulgação. O que significa dizer: o secreto com divulgação oficializada (legitimada) para um público universal. Não é um paradoxo. É uma opção artística que respeita e quer o formato livro.

Do ponto de vista exclusivamente temporal, quase não são identificados elementos de desconstrução. São mais evidentes os aspectos líricos passionais e cúmplices. Injúria ao livro é mais frequente com respeito ao seu corpo físico, principalmente quando é buscada uma representação de passagem ou ação do tempo, dependendo de o artista preferir uma retórica do passivo ou do ativo. A injúria na mensagem parece se dar mais pela perversão da função informativa do livro e pela subversão da premissa de verdade e lei contida nele. $\mathrm{O}$ dualismo ternura e injúria (que, repito, não é um antagonismo) predomina nos aspectos materiais desenvolvidos na seção adiante. Nesse momento prevalece a ternura, expressa pelo emocionalismo da confissão.

A abordagem ao livro de artista no sentido estrito deve ter em mente que ele já ultrapassou a grande fase de enunciados conceituais e das experiências sistêmicas. Pouco 
a pouco, a vontade de fazer ficção, no sentido literário do termo, avançou sobre ele. Ou melhor, os artistas foram buscá-la. O espaço da mensagem está repartido. Toda a obra artística é documento de si mesma e da sua época. Mas as obras verbo-visuais, além disso, trabalham com assertivas e com relatos. Essas construções se aproximam de territórios muito mais próximos da literatura em prosa do que da poesia. Pergunto: o texto feriu a arte ou a arte feriu o texto? $\mathrm{E}$ se ambos não têm ferimentos, a relação entre eles se dá em dependência de algum dano à percepção ou à leitura? Mais adiante tentarei compreender um pouco mais dessas relações, a partir de desenvolvimentos que parecem literários na forma, mas são, na realidade, objetos artísticos. É um assunto que envolve corpo físico e leitura através de analogias.

O estudo e a apreciação dos livros de artista, como de qualquer outra mídia lúdica, precisa de parâmetros, analogias, confrontações... Ao repassar o que foi visto, parece que é possível identificar um dualismo que passa a ser mais claro. De um lado, podemos constatar que é preconcebido ao livro sua função de curador dos registros temporais, constituintes de uma memória que se quer preservada, porque é (ou se pressupõe que seja) verdadeira (e
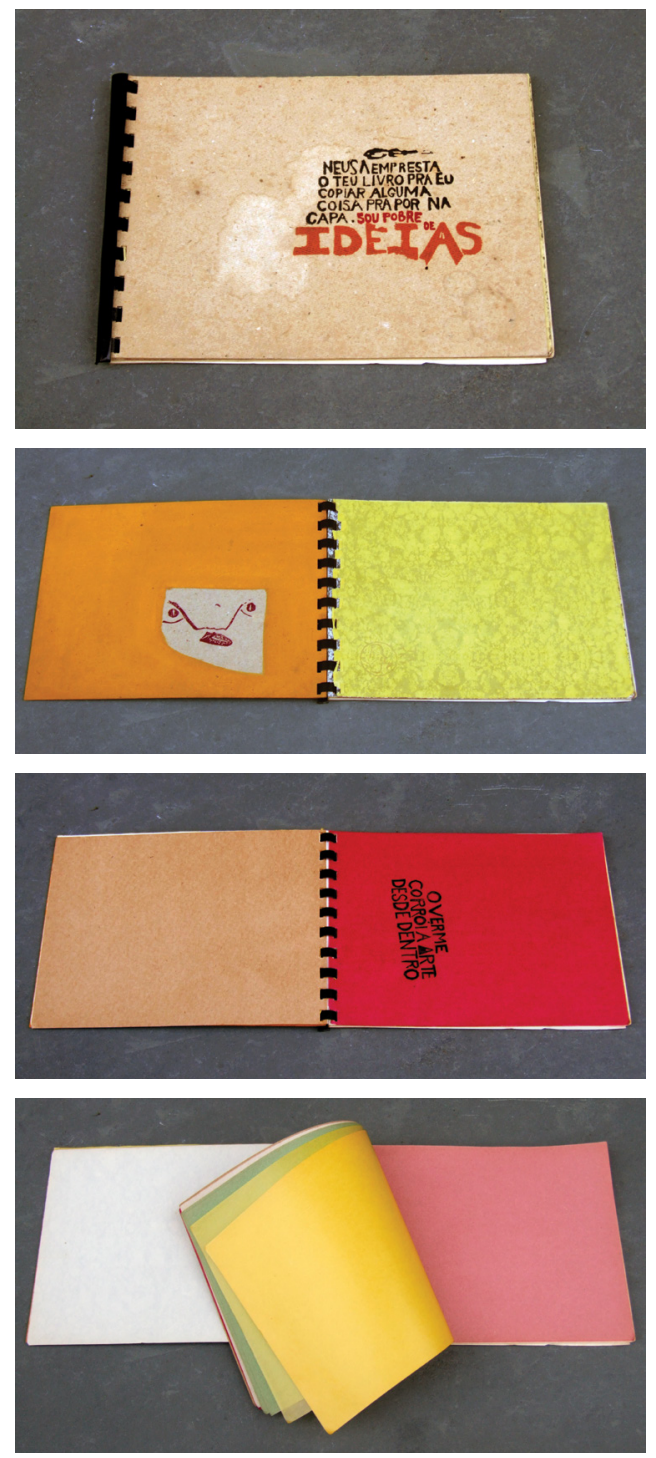

Otacílio Camilo, Caderno de ideias, s.d. poder-se-ia acrescentar que a ficção é uma verdade porque ela érealmente uma ficção).

De outro lado, a produção artística demonstra que ao livro de artista o fato pode ser maleável, especialmente quando isso servir à subversão da história pessoal do artista, da personagem ou (se projetado) do leitor. Mas não só ao livro cabe amalgamar o fato, mas a ele tem cabido, também, a sua própria transmutação em fato. Ele mesmo é o seu fato, que ocorre no seu tempo próprio. O tempo pode ser corrompido no plano da narração ou no plano da percepção, quer pela manutenção de seu perfil simbólico e de suas conformações, quer pelo dano a eles. E a memória é tão mais terna quanto mais conseguir a cumplicidade dos afetos envolvidos, não importando os danos que possam ser causados a critérios prescindíveis, como a prova ou a fé. 
A prova é a citação e vice-versa. Digo que fui ao cinema e provo mostrando o ingresso. Digo que alguém (uma personagem) foi ao cinema e uso também o ingresso. Mas ele só é prova de que eu o consegui de alguma forma. Mais nada além disso. Todo o resto é criação, ou especulação, ou metáfora. $O$ ingresso é um ingresso, mas também é cenografia. A colagem, o painel, a caixa, a assemblagem, todos concorrem para somar o tempo tornado cenográfico ao livro-objeto, especialmente o escultórico. Veja-se a esse respeito o comentário de Cláudia de Lemos sobre Anésia Pacheco e Chaves e seu trabalho apresentado com panos, desenhos, livros e outros materiais na $20^{a}$ Bienal de São Paulo, em particular o trecho em que ela registra a presença dos livros.

[...] como panos do privado que, tornados públicos [...] se ressignificam como restos mortais de camas, casas e casais. Até mesmo cadernos deles pendem como lápides. [...] Onde, com efeito, vão parar também os retratos de família e dos astros do cinema senão entre folhas grandes de grandes cadernos em que jazem o passado e seu lixo pacificado? Aí, essa mania das mulheres de guardar as lembranças, os bilhetes, os recortes, a flor seca do ramalhete do amante, uma mescla de cabelo e cintos intactos de vestidos há muito desaparecidos. [...] Anésia decreta a morte dessas lembranças. Não há nada para guardar. O que se guarda no espaço-arte-pintura criado pela moldura é apenas a teatralização do vazio de que são protagonistas os fragmentos do feminino. (Catálogo da 20ª Bienal de São Paulo, 1989, p.155)

Cadernos pressupõem registros, já vimos. Também já vimos que o formato de caderno é o preferido em obras que envolvem temas temporais, especialmente se afetivos ou líricos. Será prático, também, se o artista necessitar anexar papéis de diferentes tipos ou gramaturas, além de páginas de outros materiais (pano, plástico, lixa, borracha, madeira). A leitura de um texto tem seu tempo determinado pela habilidade de decodificação do leitor, assim como o exame de uma página em branco depende da atenção e do interesse provocados pelas relações internas do livro. Se houver mais que um artista envolvido, então haverá um diálogo gráfico e plástico com alterações de ritmo e estilo, cadenciados com histórias pessoais que, se espera, sejam relacionadas.

Terreno de circo, 1985, é uma obra conjunta (ou de colaboração) de Helio Fervenza, Otacílio Camilo e Ricardo Campos. Tem a forma de caderno mais ou menos ofício, horizontal, com páginas unidas por espiral plástica. Possui dezesseis folhas, utilizadas somente de um lado. São de papéis de diversas cores, espessuras e texturas, além de plástico e pano. Há uma folha de papel artesanal com serragem entre as fibras (serragem autêntica do circo?). Para reprodução, foi usada gravura em metal e xerografia. O volume é acompanhado por uma fita cassete de áudio. A proposta dos artistas era executar uma prospeç̧ão ao mesmo tempo conceitual e lírica de um terreno baldio de Porto Alegre, na época utilizado para acampamento de circos de lona. $\mathrm{O}$ terreno ficava ao lado do Centro Municipal de Cultura, inaugurado alguns anos antes, em fins 1978. No local, hoje ficam um ginásio de esportes e suas quadras externas. É uma área próxima ao centro da cidade, então em reurbanização, antes ocupada pou uma vila popular irregular. Dessa vila ainda restavam algumas dezenas de casas (sub-habitações), nos fundos do terreno. $\mathrm{Na}$ frente passava (e passa) uma nova avenida, moderna, com corredor de ônibus e bastante trânsito. A região era, portanto, descaracterizada, sem identidade. $\mathrm{O}$ seu passado 
era invisível (era o antigo Bairro Ilhota, por onde antes passava o arroio Dilúvio, antes da sua retificação e sujeito às enchentes), não sendo possível encontrar quaisquer vestígios do que ele tenha sido antes. Ali, a única memória possível era a recente, inserida na biografia dos artistas: a memória do paradoxo colorido das lonas dos circos em frente aos casebres de madeira. $\mathrm{O}$ resultado da experiência é uma arqueologia do tempo presente. Sua índole fica entre o bem-humorado e o crítico, instâncias onde provavelmente transitam as personalidades de Helio, Otacílio e Ricardo.

Diversos tempos estão envolvidos na obra. Mas a sequencialidade contínua, linear, não é um deles, ao menos quanto à ênfase. Ela recusa a possibilidade da sequência ser o principal elemento estruturador. Prefere insistir no ritmo, aqui um jogo de fraturas da ordem sequencial, determinado pelos momentos sugeridos pelas páginas com textos e fotos do início e do fim do livro, bem como pelas páginas que separam as pequenas gravuras. Estas, por sinal, são ao mesmo tempo fechadas em si mesmas, como valores autônomos, e relacionadas e ativadas pelo conjunto. Há, portanto, tempos de leitura, do folhear e do contemplar as imagens, como tempos do agora, do meu presente. Deve ter sido vivenciado pelos artistas, também, uma operação de presentificação da memória quando da elaboração das partes que compõem os exemplares, o que parece ter envolvido muitas etapas. Além disso, pode-se perguntar: mas existiu mesmo algum circo ali, pertencente às lembranças dos artistas? Será que essa não é uma memória construída de outras memórias? Eu sei que alguns circos estiveram ali, lembro-me de todos, mas e você, que não deve ser da
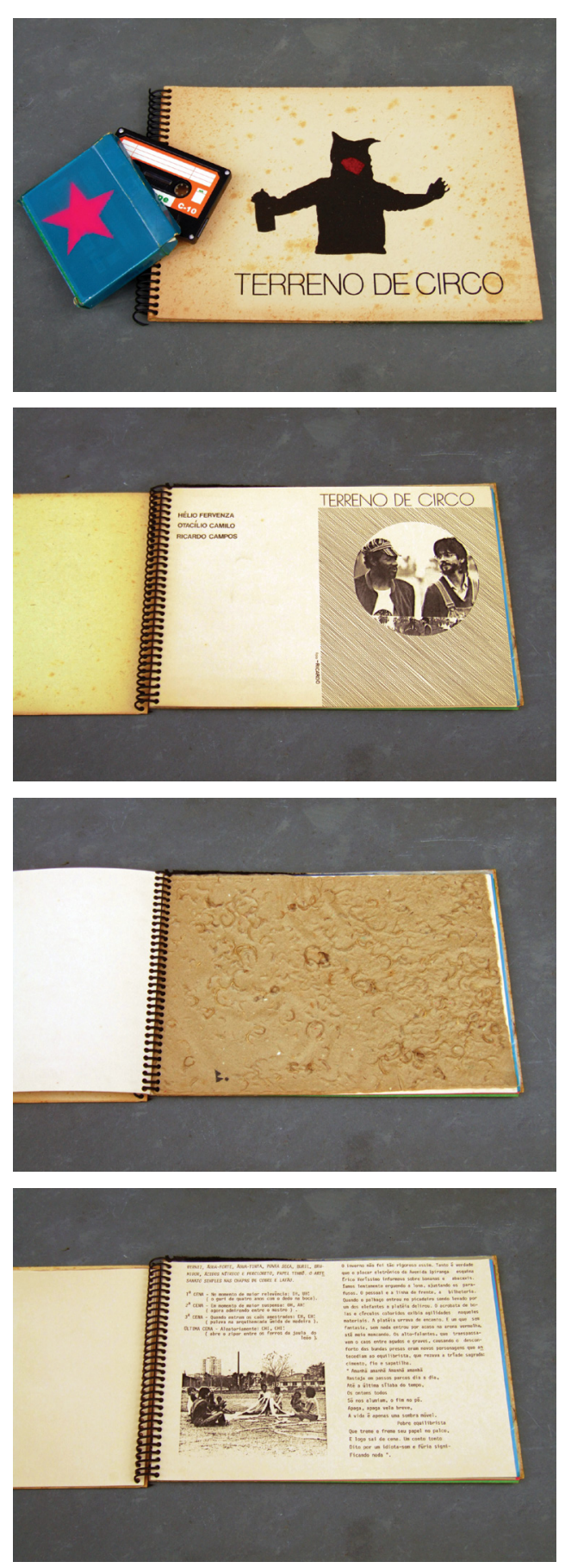

Helio Fervenza, Otacílio Camilo e Ricardo Campos, Terreno de circo, 1985. 
cidade? Afinal, não existe uma só foto que mostre um circo ali. Esse detalhe talvez possa importar pouco ou não importar nada. Talvez importe mais o sentimento de ambiguidade entre presença e ausência, muito aumentado pelos registros sonoros, na fita, dos ruídos de rua, da palavra dos curiosos, das próprias declarações: o tempo do ouvido, um vestígio além da visão.

Um terreno baldio deve ser percorrido como se fôssemos um bom cão de faro. Para um cão, o futuro só existe como resposta a estímulos condicionados. $\mathrm{E}$ o passado e o presente são quase uma coisa só. Em primeiro lugar, porque ele tem uma memória dominante inata, o instinto. $\mathrm{E}$ em segundo lugar, porque em seu mecanismo perceptivo o passado é presentificado pelo olfato. A visão, num cachorro, tem um papel equilibrado com o faro. Exemplo: em animais bem cuidados, que vivem muito, às vezes só se descobre tarde demais que estão com graus elevados de cegueira. O faro apurado preserva-lhes a orientação e a sobrevida. Quanto ao tempo, um cachorro não vê num ambiente o seu aspecto. Ele "percebe" a sua história recente. Mesmo não havendo vestígio algum, captável por nossos órgãos de sentido, um cão é capaz de "cheirar", num dado local, seja uma pessoa que por ali tenha passado (até mesmo dias antes), um gato que caçou um rato, ou um pássaro ferido que ali pousou. Enfim, sua história recente. Esse é o meio ambiente do cão. Não pelo intelecto, mas pelo sentido do olfato, o passado é o seu presente. Ele entra de corpo inteiro na narrativa. Somente o próprio cachorro sabe por que em um certo local, de repente, ele se acalma, se agita ou uiva. Algumas pessoas, por isso, acreditam que os cães veem fantasmas.
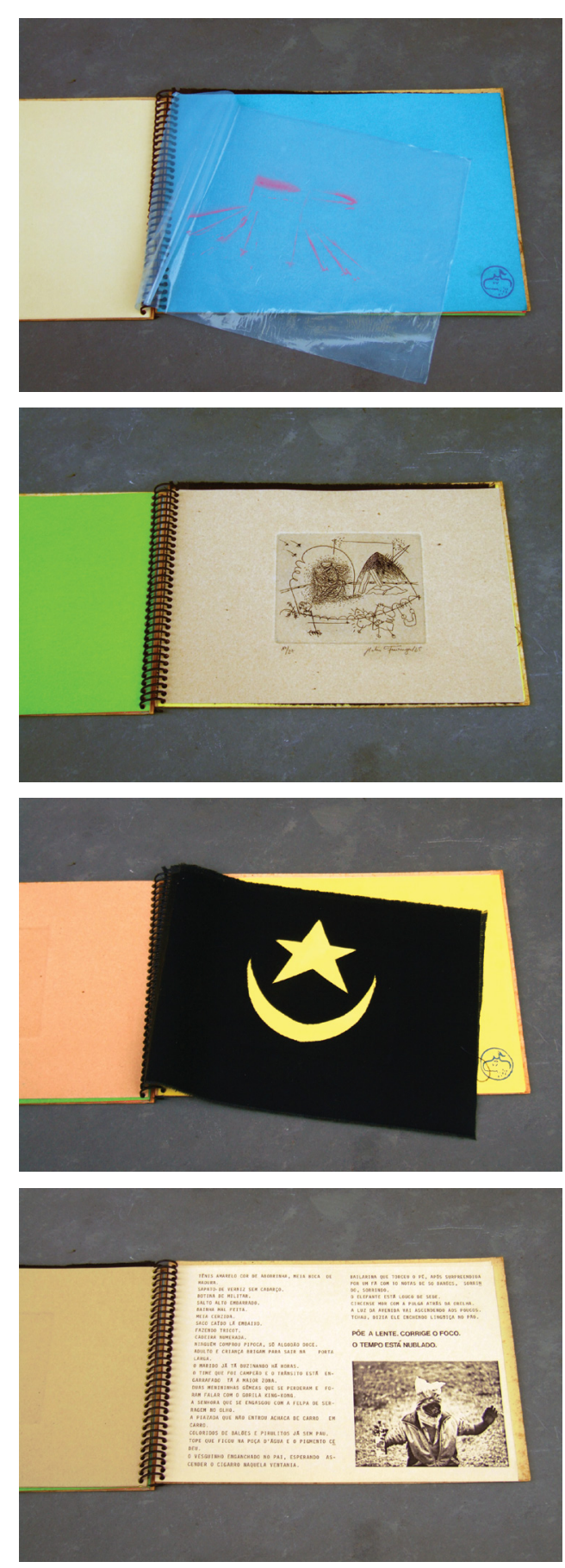

Helio Fervenza, Otacílio Camilo e Ricardo Campos, Terreno de circo, 1985. 
Aos nossos olhos são oferecidos apenas poucos indícios, poucos vestígios, que precisam ser conferidos, interpretados, para ajudar na construção de uma narrativa que poderá resultar algo incerta. Nossa relação com o tempo parece ser seguimentada. Nós o definimos, classificamos, mensuramos e usamos as medidas encontradas como mapas de nossas vidas. Marcas de nossos momentos se tornam documentos. Além de todo um ciclo de memórias, Terreno de circo guarda registros de imagem e voz de Otacílio Camilo, o Ota, falecido poucos anos depois (1959-1989). Tem agregado em si, além da memória do terreno baldio, a lembrança de Ota, que viveu entre muitos cachorros.

A marcação física dos tempos inerentes ao livro e sua inteligibilidade será discutida depois. Antes, porém, uma última série de obras pode ser apreciada, por ser desenvolvida quase exclusivamente sobre a dinâmica da sequência no livro. Além disso, as obras a seguir não possuem nenhum acabamento externo marcante, para manter o seu caráter lúdico desvencilhado de recursos estetizantes.

Vera Chaves Barcellos tem seu currículo quase todo dedicado aos problemas conceituais da arte, da percepção e da integração do indivíduo em sistemas. Sua obra é, por isso, essencialmente sistêmica. Fez poucos livros, mas utilizou-se intensamente da potência temporal inerente a eles, ao gesto de folhear e à perscrutação da página, para esculpir a memória adquirida do leitor observador. Nos seus livros a sequencialidade é amplificada pelo ir e vir: a lembrança do que já foi e a expectativa do que será. $\mathrm{O}$ aspecto lúdico é sempre primordial ao aspecto gráfico e normalmente ativado pelo uso da fotografia. Como volumes, seus livros são

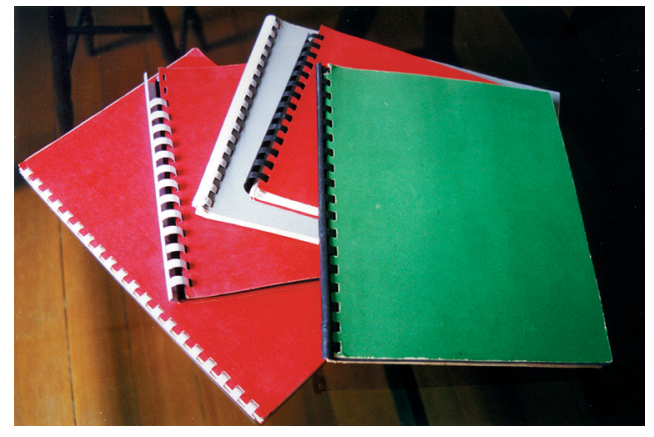

Vera Chaves Barcellos, cadernos.
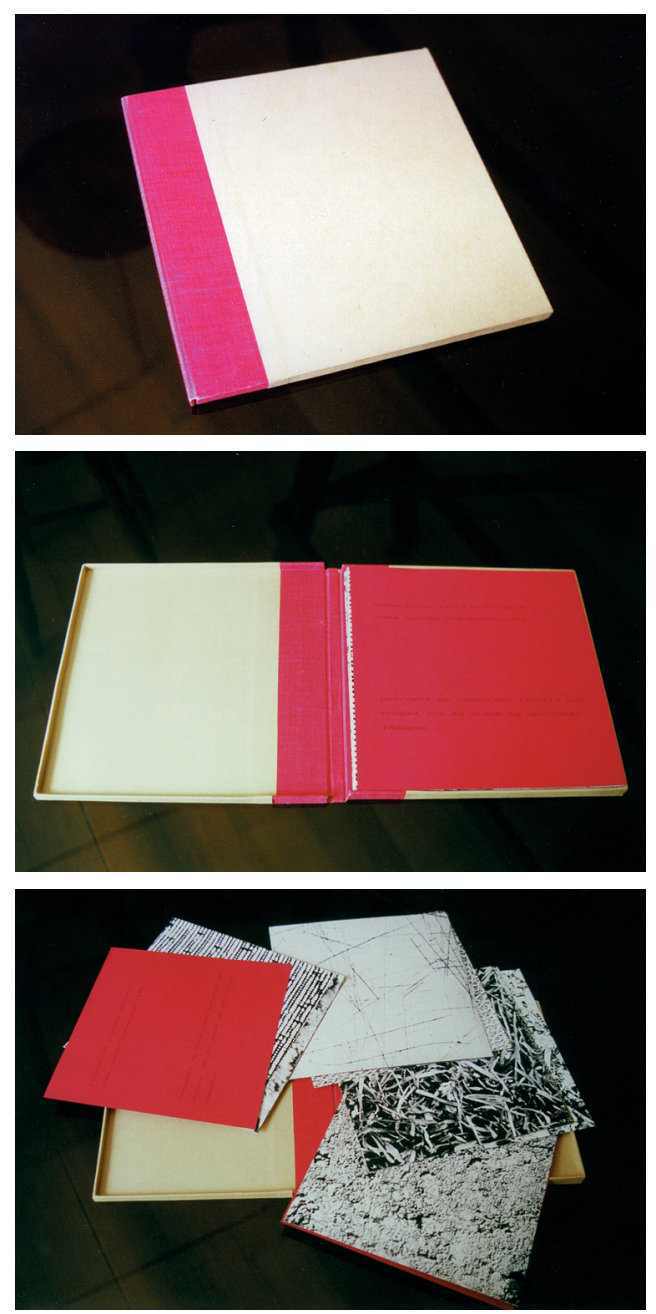

Vera Chaves Barcellos Exercícios visuais-tácteis, 1975. 


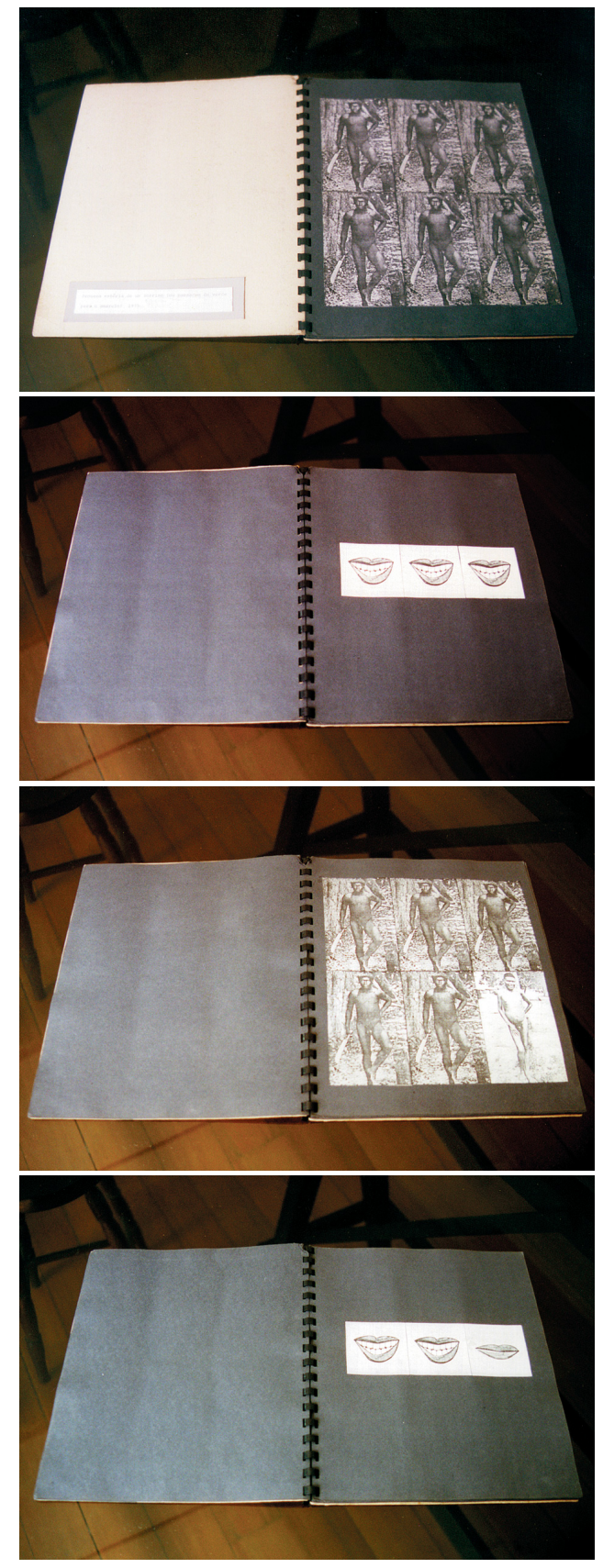

Vera Chaves Barcellos, Pequena história de um sorriso (ou Passagem do verde para o amarelo), 1975.
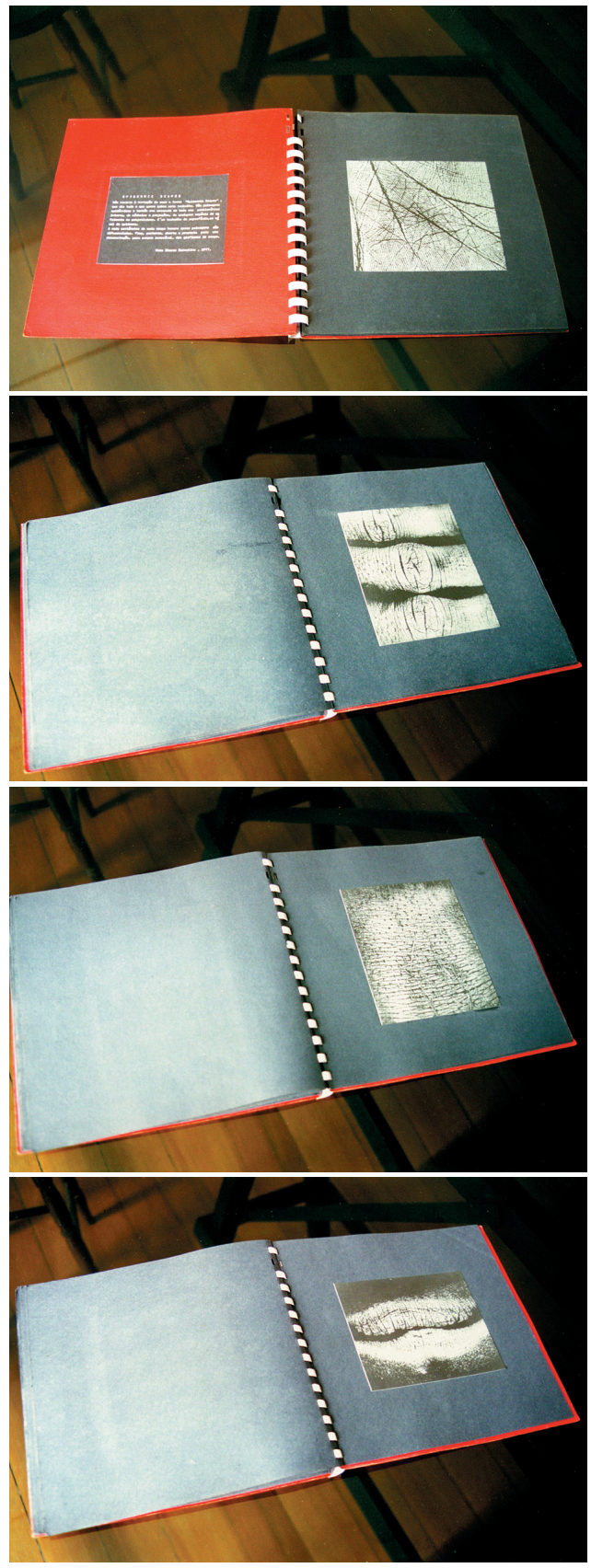

Vera Chaves Barcellos, Epidermic scapes, 1977. 
extremamente despojados. Embora ela tenha produzido com preciosismo (Exercicios visuais-tácteis, 1975), seus outros trabalhos são cadernos simples, normalmente compostos por colagens que utilizam a fotocópia, em tamanhos "ofício". A encadernação, como tal, praticamente inexiste. As páginas são unidas por espirais plásticos e os volumes têm capas inexpressivas semi-sintéticas, cinzas ou de cores neutras, dessas utilizadas em lojas de fotocópias. As capas nem mesmo têm títulos. Para Vera, o primordial é o exercício. Importa-lhe a obra ativa, mais que a obra passiva.

Em Pequena estória de um sorriso (ou passagem do verde para o amarelo), 1975, um grupo de imagens de um índio forte e saudável é aos poucos alterado pela substituição de uma a uma pela imagem de um índio aculturado, sorridente e patético. Essa sequência é acompanhada por uma segun$\mathrm{da}$, de desenhos de bocas sorrindo trocadas aos poucos por bocas sérias. Esse trabalho apresenta uma direção linear, onde uma página (ou folha) pede pela sua posterior, até uma conclusão. O livro "narra".
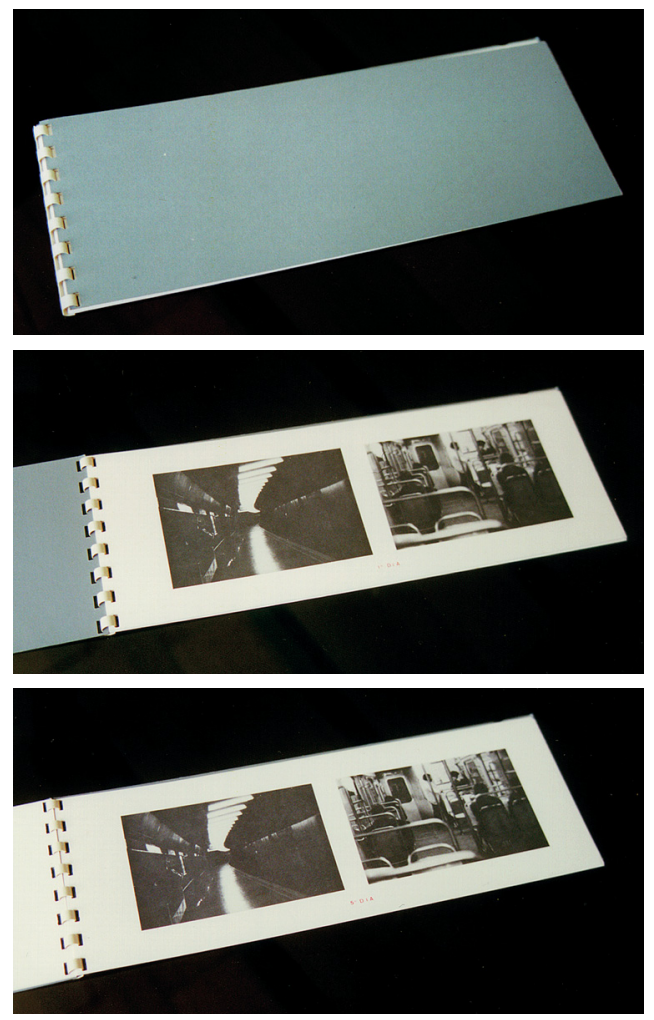

Vera Chaves Barcellos, Da capo, 1979.

Epidermic scapes, 1977, também na versão em cartaz, não tem sequencialidade explícita. Ele acompanhou outros projetos homônimos da artista. Cada página contém uma grande ampliação fotográfica da impressão de uma pequeníssima área da superfície do seu corpo. No verso da capa, Vera apresenta sua proposta de documentação: "São paisagens epidérmicas e também uma escapada de toda uma problemática interna, de símbolos e projeções, de qualquer espécie de sofrimento ou subjetivismo. É um trabalho de superfície, ao nível da epiderme.”Em ordem inversa, Da capo, 1979, terá todas as páginas com as mesmas fotos, absolutamente iguais (interior de estação do metrô e interior de um vagão), legendadas com a ordem dos dias que passam. Haverá uma sequência subliminar: a ideia do passar dos dias, iguais, um após o outro. Esses são livros que "descrevem".

Em Atenção - processo seletivo do perceber, 1980, retorna o jogo. Não é um, mas sim dois livros também na forma de cadernos, que propõem o exercício da memória como participante do processo perceptivo. Um dos livros traz em suas páginas um pequeno seguimento quadrado de uma foto maior de multidão, externa e independente ao livro, que será uma espécie de mapa de onde ele saiu. Nossos olhos saem e retornam das páginas 
para a foto, focalizando tempos e espaços diferentes, fazendo agora a perícia de um momento passado. No outro livro, página após página uma outra foto de multidão se repete, sem nenhuma alteração. É sempre a mesma foto. Mas dessa vez elas têm legendas que conduzirão o nosso olhar: "a temperatura é amena e as pessoas usam roupas leves...", ou "os guarda-chuvas abertos, com o início da chuva...", ou ainda "um menino segurado pela mãe”. Os dois livros estiveram integrados a um projeto conceitual maior, de discussão dos princípios da atenção. Eles são livros que "dissertam".

Vera produziu apenas um livro somente com texto, Movimento vital, 1979, em fotocópias. Nele, o único texto é manuscrito, um pouco a cada página: “eu”, depois “eu estou”, depois “eu estou aqui”, mais adiante "eu estou aqui presente agora olhando", até a conclusão da ideia. Se a primeira palavra é "eu”, a última é "fim". O trabalho tem um lirismo sedutor que integra o seu leitor ao próprio ato de ler e ao próprio caderno que ele tem nas mãos. Esse lirismo diferencial em sua obra é, como se pode imaginar, fruto de uma situação também diferencial.

Tinha circunstâncias pessoais, assim, que me provocaram de estar trabalhando menos nessa época. Que foi o ano de 79, se não me falha a memória. Então, eu tive essa ideia... Me lembro que eu estava indo para Carazinho, meu pai estava mal, doente, e no carro, sozinha, tive essa ideia de fazer esse livro. Uma coisa, assim, muito circunstancial. E é dos poucos momentos que eu me lembro exatamente quando eu tive a ideia, não é? Puxa, eu vou fazer um livro assim, vai começar com "eu”, "eu estou aqui”, aquela presença, não é?, e vai ser só texto, eu vou escrever com manuscrito, e tal, então vou fazer uma tiragem, xerox, enfim... E fui desenvolvendo a ideia...
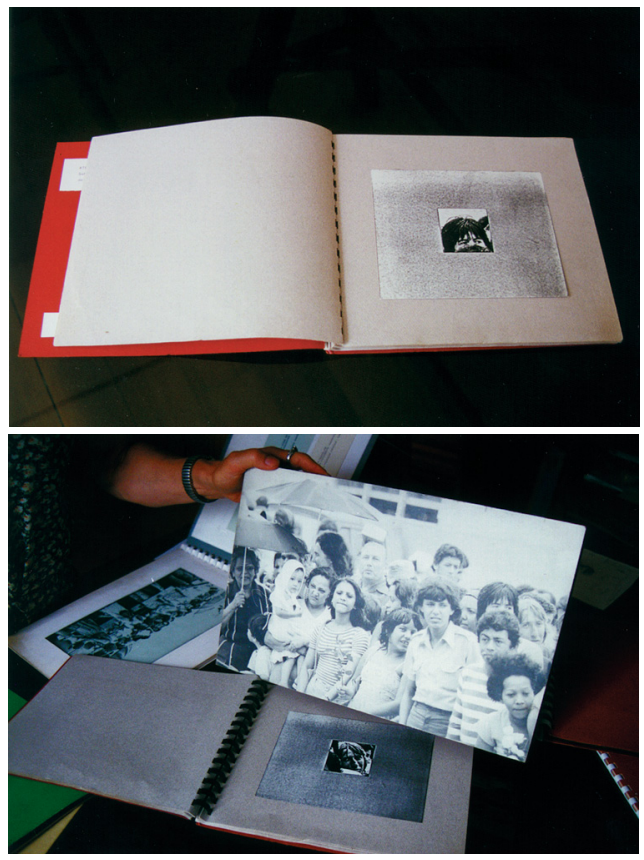

Vera Chaves Barcellos, Atenção-Processo seletivo do perceber, 1980.
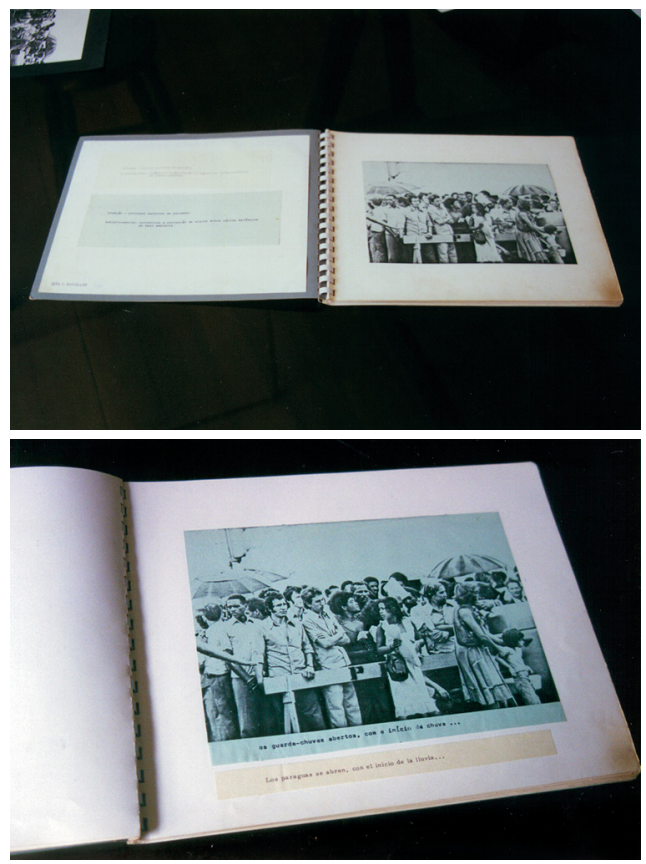

Vera Chaves Barcellos, Atenção-Processo seletivo do perceber, 1980. 
Quando cheguei lá em Carazinho, já estava pronta a ideia do livro. Depois eu fiz. (Depoimento para esta pesquisa.)

Araci Amaral (em Vigiano, 1986, p.34) observa essa diferença de atitude estética.

Se a Pequena bistória de um sorriso é indicativa de uma preocupação social através de suave ironia, já Momento vital (1979), de natureza concreta, nos remete como observador como uma fusão com o autor do trabalho, em experiência singular, sobretudo em suas primeiras páginas, onde não há margem para dicotomias que romperiam o "segredo" dessa íntima relação autor/leitor.

A presença da decifração como fundamento da relação entre a obra e o fruidor oferece a "coerência interna da trajetória dos trabalhos de Vera”, segundo Icleia Cattani.

Mas a construção de tais jogos passa pela desconstrução da imagem de partida: da totalidade faz-se fragmentos que, decifrados, permitirão reconstituir a imagem. Com uma sutil diferença: a imagem reconstruída guardará para sempre os cortes dos fragmentos, como cicatrizes. Sua "unidade” será a reconstituição de seus pedaços. (Kern, Zielinsky e Cattani, 1995, p.189)

Difícil desconstruir o tempo, é muito mais fácil a metáfora através da desconstrução do corpo físico ou imagético do livro. Esse é, portanto, um momento de passagem entre tempo e espaço. É a confirmação no livro, bem como neste esforço de entendimento, do exercício de sua esquize: ativação e personificação dos seus diferentes tempos na fundação de um só corpo.

Vera Chaves Barcellos, performance com Momento vital, 1979 (Espaço NO, p.10).
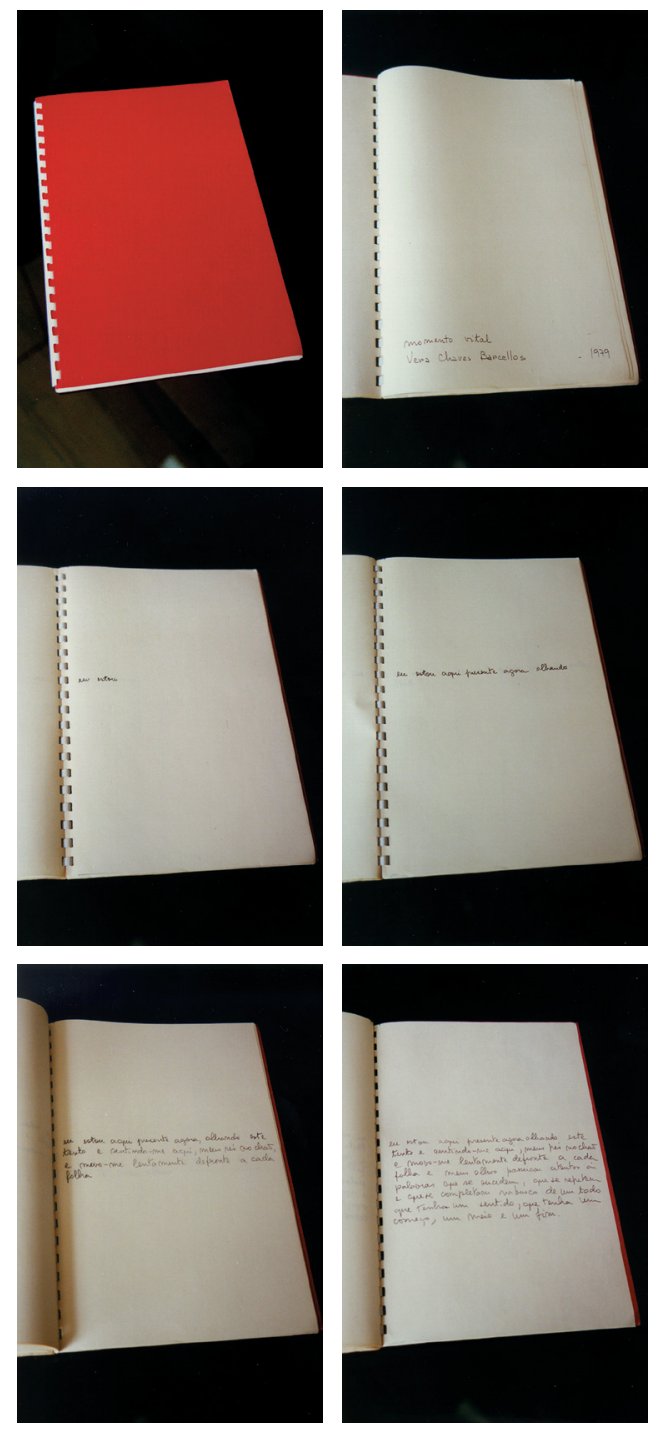

Vera Chaves Barcellos, Momento vital, 1979.

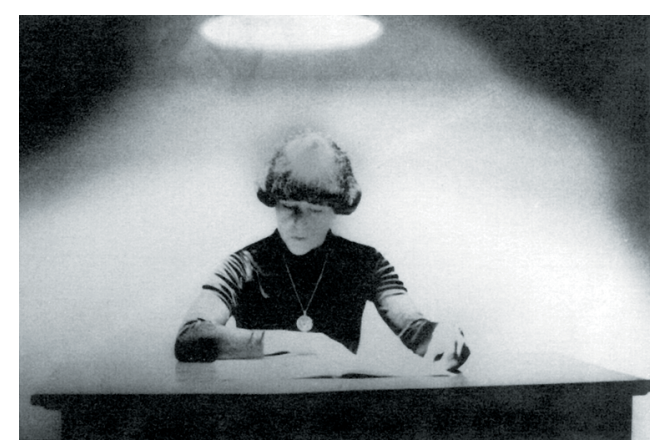

